\title{
Dapingian-lower Darriwilian (Ordovician) stratigraphic gap in the Faraghan Mountains, Zagros Ranges, south-eastern Iran
}

\author{
MOHAMMAD GHAVIDEL-SYOOKI, LEONID E. POPOV, J. JAVIER ÁlVARO, \\ MANSOUREH GHOBADI POUR, TATIANA Y. TOLMACHEVA \& MOHAMMAD-HOSSEIN EHSANI
}

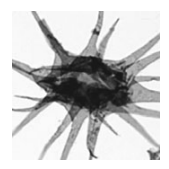

\begin{abstract}
The Lower-Middle Ordovician sediments exposed in the Faraghan Mountains, south-eastern Zagros Ranges, represent a condensed succession of siliciclastic-dominated rocks rich in palynomorph assemblages (acritarchs and subsidiary chitinozoans) and sparse shelly concentrations bearing biostratigraphically significant brachiopods and conodonts. The Lower Ordovician Zard-Kuh Formation comprises coarse-grained siliciclastic deposits rich in Cruziana ichnofossils. The lower $80 \mathrm{~m}$ of the overlying Seyahou Formation, late Floian to Katian in age, form a heterolithic succession composed of black and green shales, subarkoses and silty limestones. Its lower part is punctuated by a centimetric phosphoarenite that contains lingulate brachiopods (Atansoria yaseri sp. nov.) and conodonts (Baltoniodus aff. B. triangularis Lindström and Drepanoistodus sp.) that suggest a latest Floian age. The top of the condensed phosphoarenite is marked by a considerable hiatus that ranges the Dapingian and early Darriwilian interval. Overlying the hiatus, the Seyahou Formation comprises two fossiliferous levels, the oldest dated as mid-Darriwilian with chitinozoans characteristic of the Siphonochitina formosa Zone, and the youngest of the Katian Acanthochitina barbata Zone. Mid Ordovician phosphogenesis associated with starvation, reworking, resedimentation, and the onset of distinct stratigraphic gaps was a complex process recorded throughout the Arabian margin of Gondwana. In the Zagros Ranges, maximum flooding and phosphate precipitation are suggested as the counterpart of the Helskjer Drowning Event of Baltoscandia and the third-order maximum flooding surface that punctuates the Siphonochitina formosa Zone in North Africa. $•$ Key words: chitinozoans, conodonts, acritarchs, brachiopods, stratigraphy, Gondwana.
\end{abstract}

Ghavidel-Syooki, M., Popov, L.E., Álvaro, J.J., Ghobadi Pour, M., Tolmacheva, T.Y. \& EhSAni, M.-H. 2014. Dapingian-lower Darriwilian (Ordovician) stratigraphic gap in the Faraghan Mountains, Zagros Ranges, south-eastern Iran. Bulletin of Geosciences 89(4), 679-706 (11 figures, 2 tables). Czech Geological Survey, Prague. ISSN 1214-1119. Manuscript received May 28, 2013; accepted in revised form December 14, 2013; published online July 8, 2014; issued September 30, 2014.

Mohammad Ghavidel-Syooki, Institute of Petroleum Engineering, Technical Faculty of Tehran University, P.O. Box 11365-4563, Tehran, Iran; m_ghavidelsyooki@yahoo.com • Leonid E. Popov, Department of Geology, National Museum of Wales, Cathays Park, CardiffCF10 3NP, United Kingdom; leonid.popov@museumwales.ac.uk - J. Javier Alvaro, Centre of Astrobiology (CSIC/INTA), Ctra. de Torrejón a Ajalvir km 4, 28850 Torrejón de Ardoz, Spain; alvarobjj@cab.inta-csic.es - Mansoureh Ghobadi Pour, Department of Geology, Faculty of Sciences, Golestan University, Gorgan 49138-15739, Iran; mghobadipour@yahoo.co.uk•Tatiana Y. Tolmacheva, Department of Stratigraphy and Palaeontology, Russian Geological Research Institute (VSEGEI), 74 Sredniy Prospect, 199106 St. Petersburg, Russia; Tatiana_tolmacheva @vsegei.ru・Mohammad-Hossein Ehsani, Institute of Petroleum Engineering, Technical Faculty of Tehran University, P.O. Box 11365-4563, Tehran, Iran; mh_ehsani@hotmail.com

After the Pan-African amalgamation of the Arabian-Nubian shield, the uppermost Ediacaran-lower Cambrian sediments on both sides of the Persian Gulf, including thick accumulations of salt (Hormoz and Ara salt plugs), suggest that the Arabian margin of Gondwana recorded a rifting phase with active intracratonic extension. The end of this phase was accompanied by a major episode of tilting and uplift, which led to the record of forced regressive pulses and widespread ero- sion in some areas, such as in the Arabian Peninsula. By the Early Ordovician, sea-level rise peaked to a highstand and the Arabian margin (then a peneplaned platform with low subsidence rates) was again blanketed with marine sediments (Husseini 1989, 1990; Oterdoom et al. 1999; Sharland et al. 2004; Konert et al. 2011).

The Zagros platform formed part of the Arabian margin of Gondwana. Therefore, it is not surprising that the 


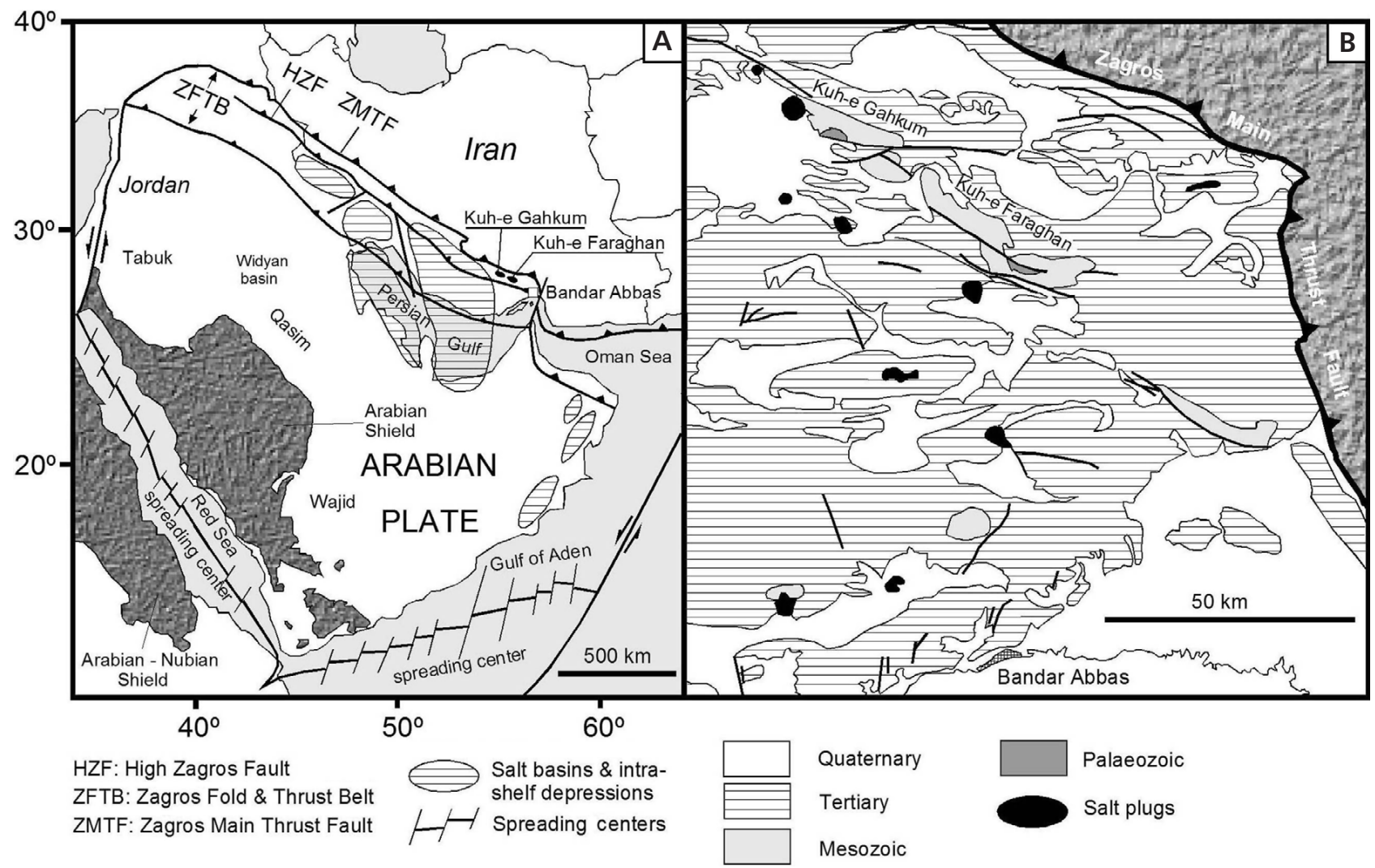

Figure 1. A - major tectonic features of the Arabian Plate, the Zagros Mountains, and adjacent areas; modified from Heydari (2008) and Ghavidel-Syooki et al. (2011). B - geological map of the study areas in the southeastern Zagros Fold and Thrust Belt, North of Bandar Abbas; modified from Afaghi \& Salek (1977) and Ghavidel-Syooki et al. (2011).

Cambrian-Llandovery (Silurian) sequences of the Zagros Ranges (well exposed in the Faraghan and Gahkum Mountains) show distinct stratigraphic similarities to the contemporaneous sequences documented in the Arabian Peninsula (Ghavidel-Syooki \& Khosravi 1995, Rickards et al. 2000).

The aim of this paper is to control the onset and range of Lower-Middle Ordovician stratigraphic gaps in the Faraghan Mountains (Zard-Kuh and Seyahou formations, the former recognized for the first time in the area), based on facies and biostratigraphic analyses. The biostratigraphic constraint of the succession is based on both palynomorphs (acritarchs and chitinozoans) and shelly fauna (brachiopods and conodonts). A comparison with neighbouring areas will allow a better understanding of the rift evolution of the Arabian margin of Gondwana.

\section{Geological setting and stratigraphy}

The Zagros Ranges are a fold-thrust belt located in the northeastern margin of the Arabian Plate. There, Ordovician-Silurian rocks crop out only in two massifs, north of Bandar Abbas, named Faraghan and Gahkum Mountains (Fig. 1). The Ordovician-Silurian exposures of the Farag- han Mountains were under extensive geological studies since the 1920 s, but the information was mainly stored in unpublished internal reports of the former Anglo-Iranian Oil Company and only came into light in Rickards et al.'s (2000) synthesis. The first substantial study of the Palaeozoic sequence in the area was published by GhavidelSyooki \& Khosravi (1995), who subdivided the exposed strata into the Seyahou (Middle to Upper Ordovician) and Sarchahan (uppermost Ordovician-Silurian, Llandovery) formations (Fig. 2). Their biostratigraphy and correlation were subsequently based on palynological studies (Ghavidel-Syooki 1998, 2000; Ghavidel-Syooki \& WinchesterSeeto 2002) and preliminary reports of graptolites (Rickards et al. 2000). Recently, Ghavidel-Syooki et al. (2011) have documented the presence of Hirnantian glaciogenic strata, which have been lithostratigraphically assigned to the Dargaz Formation.

\section{Material and methods}

This work has two components: facies analyses involving field and petrographic observations of rocks, and palaeontological studies. Forty samples were collected from 
Mohammad Ghavidel-Syooki et al. • Dapingian-lower Darriwilian stratigraphic gap in the Faraghan Mountains

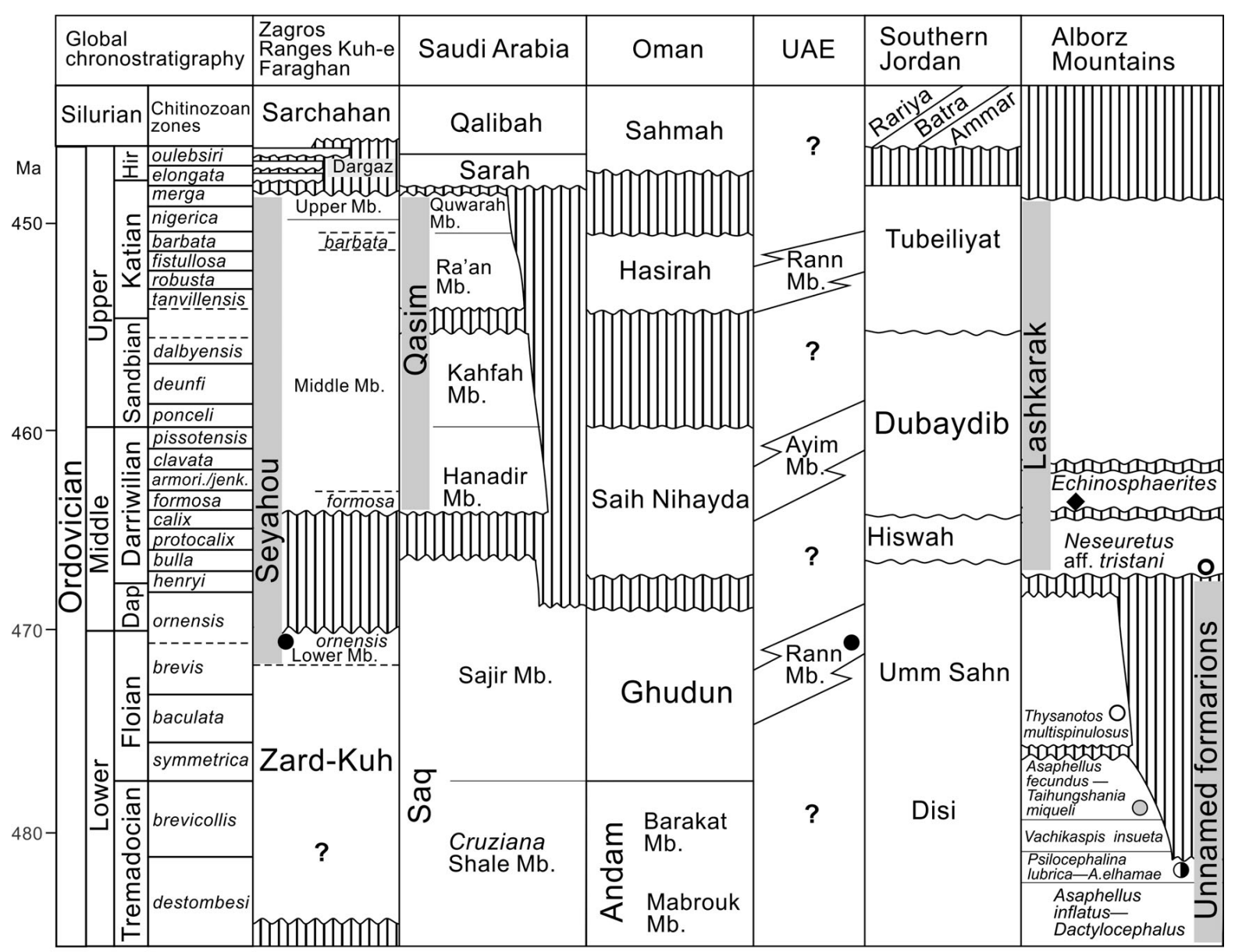

Conodont occurrences in Iran and UAE: Paltodus deltifer; O Drepanodus aff. amoenus; O Prioniodus elegans

Baltoniodus aff. B. triangularis; O Lenodus variabilis; $>$ Lenodus pseudoplanus.

Figure 2. Summarized Ordovician chrono- and lithostratigraphic chart of the Arabian margin of Gondwana, based on Vaslet (1990), Armstrong et al. (2005), Clark-Lowes (2005), Turner et al. (2005, 2012), Molyneux et al. (2006), Rickards et al. (2010), Ghavidel-Syooki et al. (2011), and this work; and Ordovician chrono- and lithostratigraphic chart of Alborz Region, Iran based on Ghobadi Pour (2006) and Ghobadi Pour et al. (2007, 2011). North Gondwanan chitinozoan biozones after Paris in Videt et al. (2010).

Lower-Middle Ordovician exposures in the Faraghan Mountains for thin-section and petrographic study. A total of 19 samples from the lower $75 \mathrm{~m}$ of the Seyahou Formation were chemically treated for microfossil extraction. The latter succession is exposed at the southern foothills of the Faraghan Mountains. The presence of the Lower Ordovician Zard-Kuh Formation is recognised for the first time in the area; however, rocks referred to this formation are barren. The Seyahou Formation within whole studied intervals contain well-preserved and abundant organicwalled microphytoplankton (acritarchs) and significantly less common chitinozoans. Majority of acritarchs and organic debris range in colour from yellow to orange, indicating a relatively medium thermal maturity for the organic material.

Palynomorphs were extracted from shales using a standard palynological technique of treatment in hydrochloric and hydrofluoric acids to remove carbonate and silicate, re- spectively, and neutralising residues in distilled water after each acid treatment (see e.g. Jenkins 1967, Paris 1981). The samples were not oxidised and organic residues were concentrated using density separation in Zinc bromide solution with a specific relative density of 1.95 . The organic residue was then sieved through a $15 \mu$ m nylon mesh sieve in order to eliminate the finer debris and facilitate palynological analyses. Palynological preparations were then studied using transmitted light and scanning electron microscope (Cam Scan MV2300) in the Technical Faculty of the Tehran University.

Conodonts and organophosphatic brachiopods were isolated from carbonate rocks by etching in weak (10\%) acetic acid using standard techniques (Jeppsson et al. 1999). After coating with gold palladium they were studied under a scanning electron microscope using a Cam Scan MaXim 2040S SEM with variable vacuum chamber in the Archaeology Department, Cardiff University, UK. 

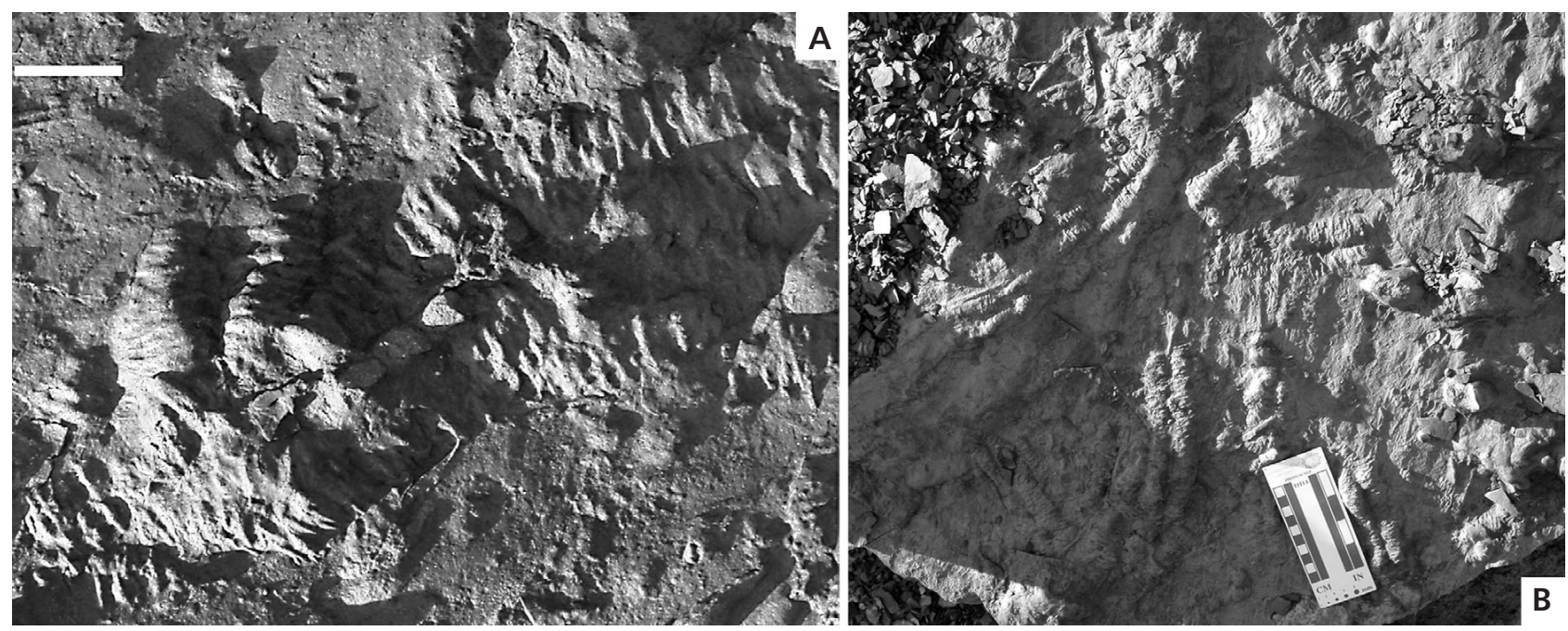

Figure 3. Trace fossils from the Cruziana beds of the Zard-Kuh Formation. - A - enlarged view of Cruziana imbricata Seilacher, 1970 ; scale bar is $2 \mathrm{~cm} . \cdot \mathrm{B}-$ general view of a bedding surface infested with numerous Cruziana trace fossils.

\section{Facies associations and palaeoenvironmental interpretation}

\section{Zard-Kuh Formation}

The lowermost Ordovician lithostratigraphical unit exposed in the Faraghan Mountains is the Zard-Kuh Formation. It was introduced by Setudehnia (1975), who selected a type section located at Zard-Kuh (Kuh = mountain in Farsi; Central Zagros). An isolated exposure of coarse- to medium-grained litharenites and siltstones in the lower part of the Zard-Kuh Formation at $1 \mathrm{~km}$ west of the studied section [27 $51^{\prime} 49^{\prime \prime} \mathrm{N}, 56^{\circ} 18^{\prime} 56^{\prime \prime}$ E] locally contains Cruziana ichnofossils on sandy surfaces, such as Cruziana imbricata Seilacher, 1970 (Fig. 3). Within the section, the upper part of the Zard-Kuh Formation (Fig. 2), reported as lower member of the Seyahou Formation in GhavidelSyooki et al. (2011, fig. 1), is $20 \mathrm{~m}$ thick. It consists of polymictic, poorly sorted conglomerates changing upsection into pebbly, very coarse- to medium-grained litharenites arranged as both trough and tabular sets of cross-strata. Conglomerate displays a varied clast composition, including quartz, quartzite, chert, feldspar and metamorphic clasts. The sequence of crudely stratified, poorly sorted conglomerate and pebbly litharenite might represent deposition of meandering bars, whereas the stratified tabular sets of cross-strata would represent deposition of sand waves migrating across channel bottoms. Cruziana ichnofossils mark starvation on shoal surfaces during episodes of energetic fall. The occurrence of channelised conglomerates reflects high-energy conditions and an active source area, the latter related to either a sharp fall in relative sea level or the onlapping patterns on an unpreserved palaeorelief of unkown palaeotopography, due to reduced extension of available exposures.

\section{Seyahou Formation}

The lower and middle members of the Seyahou Formation form a heterolithic succession composed of black and green shales, grey subarkoses and silty limestones. The thicker interbeds are shales both greenish and blackish; the latter are black when freshly broken. Colour contacts are sharp but ichnofossils can crosscut them. Oxygen levels of the substrate were sufficient, at least episodically, to render the seafloor suitable for colonization by burrowing metazoans. Despite the black colour of some shale packages, burrowing of these sediments suggests that deposition took place in well-oxygenated water below normal wave base. Oil inclusion is secondary, probably facilitated by diagenetic fracturing of strata.

A single shelly phosphoarenite bed, up to $8 \mathrm{~cm}$ thick, marks the top of the lower member of the Seyahou Formation. It represents a shell lag concentration of valves of linguliformean brachiopods, such as Atansoria yaseri sp. nov. and unidentified lingulides, and the conodonts Baltoniodus aff. B. triangularis (Lindström, 1955) and Drepanoistodus sp. (sample MG10002/1). The shells are commonly broken and their fragments chaotically arranged, although laterally they also show imbricated arrangements (Fig. 4A, B). The level contains hardground-derived clasts and both fragmented and subsidiary articulated specimens in ecologically mixed, but littletransported (parautochthonous), benthic and pelagic assemblages. Pockets of undisturbed silty sand, in the otherwise well-sorted sand matrix, with variable fossil preservation suggest condensation in an offshore setting, punctuated by episodes of reworking and resedimentation. Although most fossil occurrences consist of disarticulated and broken elements, in which the skeletal and grain edges show considerable rounding, a large number of articulated 

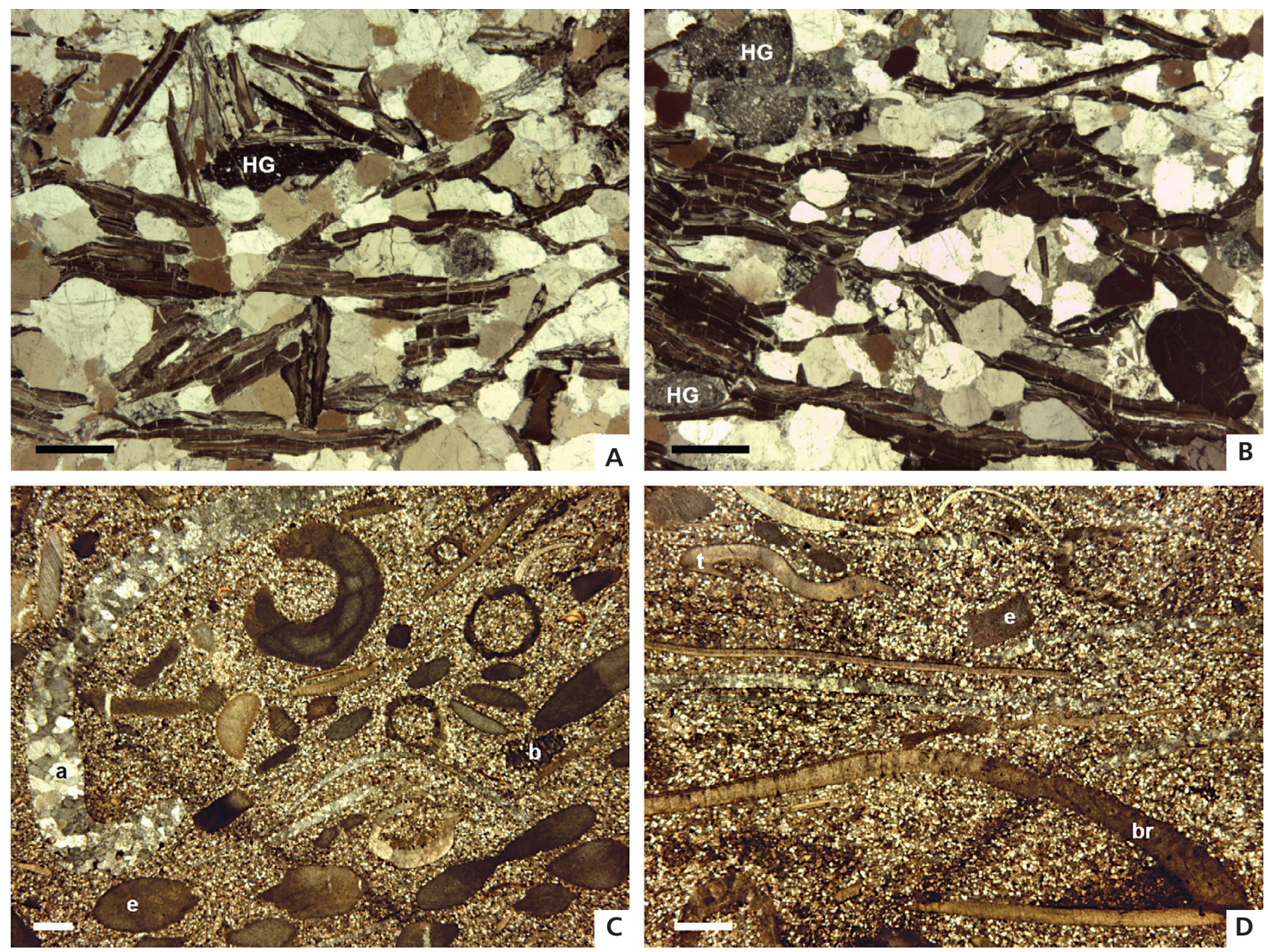

Figure 4. Photomicrographs (transmitted light) of phosphoritic and limestone beds from the Seyahou Formation stratotype. $\bullet$ A, B - phosphoarenite rich in linguliformean brachiopods and hardground-derived clasts (HG), sample MG10002/1. • C, D - silty wackestone-packstone rich in calcite- and aragonite-walled (a) brachiopods (br), bryozoans (b), echinoderm ossicles (e) and trilobite sclerites (t), sample MG KF3b.

brachiopods have been extracted after etching. Concentration of phosphate debris suggest that deposition on the seafloor was inhibited for sufficient intervals of time to allow the substrate/water interface to be indurated by authigenic (apatite) cementation as well as reworked and physically abraded. Mechanical compaction and pressure-dissolution features include reorientated and deformed shells, displaying interpenetrative grains, fitted fabrics, solution seams, and microstylolites. The top of the phosphoarenite bed represents a nondeposition surface.

Sandstone interbeds, 10 to $40 \mathrm{~cm}$ thick and exhibiting abundant pinch and swell, are abundant. Their most common primary sedimentary structures are parallel to low-angle cross-lamination, hummocky cross- and convoluted stratification. The parallel and low-angle laminae grade laterally into broadly undulant laminae. The size of the hummocks increases with increasing bed thickness and sand content. Bed tops also display symmetric ripples. The thinner-bedded and finer-grained sandstone interbeds con- tain burrowing. The thicker sandstone beds, which contain sharp, scouring bases, localized channelling, and internal discontinuities, were the product of strong erosive flows.

Two silty limestone beds, up to $60 \mathrm{~cm}$ thick, are interbedded in the upper part of the section. Both display scouring bases and crude parallel to low-angle lamination of their skeletal component, mainly composed of disarticulated and broken brachiopods, including Tafilatia sp. (Fig. 4C, D; sample MG KF3b, Fig. 5) trilobites, bivalves, cystoid and crinoidal echinoderms, and bryozoans. Matrix is a variable mixture of very fine- to medium-grained sand and shell fragments. It is interpreted to have been deposited in nearshore, high-energy settings.

\section{Depositional trends}

The studied Zard-Kuh/Seyahou stratigraphic log of the Faraghan Mountains exhibits a transgressive/regressive composite 
sequence, with a lower transgressive systems tract (TST) and an upper highstand systems tract (HST), separated by a phosphoarenitic maximum flooding surface (MFS; Fig. 5).

The TST shows an upsection change from conglomerate to sandstone and sandy shale, characteristic of a gradual transition from continental (?) to nearshore depositional environments. The lack of laterally equivalent exposures precludes a definitive sedimentological assignation of the Zard-Kuh basal conglomerates.

Evidence of an abrupt upward deepening of facies, culminating in a level of deepest or most offshore facies, corresponds to the onset of a phosphoarenite bed that marks the top of the lower Seyahou Member. The bed corresponds to the time of maximum water depth in the Zagros Platform generating a condensed horizon (surface representative of episodic starvation, reworking and redeposition) with concentration of hardground-derived clasts and microfossils, mainly brachiopods and linguliformean brachiopods (sample MG 10002/1). Its top is marked by an omission surface representing sediment starvation or nondeposition. Its stratigraphic gap will be estimated below based on shelly and organic-walled microphossils.

The overlying HST consists of sandstone/shale alternations where high-energy currents or sustained wave action concentrated sand, and adjoining areas of low energy conditions received clay deposits, producing the typical sequence of interbedded sandstones and shales. Impure carbonates occurred at two levels: its argillaceous and sandy composition shows that shelly carbonate production and siliciclastic deposition intergraded. Finally, the upper member of the Seyahou Formation consists of shoal complexes and tidalites that represent the end of the HST, subsequently capped by a glaciogenic Hirnantian unconformity (Ghavidel-Syooki et al. 2011).

\section{Biostratigraphy}

The biostratigraphic control of the studied stratigraphical interval is based on brachiopods, conodonts, chitinozoans and acritarchs (Figs 5, 6).

\section{Brachiopods}

Only two brachiopod species have been recovered, thus their biostratigraphic application is rather limited. Among them Atansoria yaseri sp. nov. belongs to a lingulid genus, previously known from the Upper Ordovician of Kazakhstan and the Australasian sector of Gondwana (Popov 2000), and is reported here from a phosphoarenite that marks the top of the lower Seyahou Member (sample MG10002/1; Fig. 5). Tafilatia sp. occurs in a shell bed included in the Acanthochitina barbata Zone (sample MG
KF3b). It probably represents a new species, which shows some similarities to Tafilaltia brevimusculosa Villas, 1995 from the Katian Bancos Mixtos of Central Spain.

\section{Conodonts}

Although more than 1000 conodont elements were recovered after etching from the reported phosphoarenite (sample MG10002/1; Fig. 5), only three species can be discriminated with confidence and they are discussed in the systematic part. Conodonts are dark grey to black (CAI 4-5), and most of them broken.

Almost $30 \%$ of counted elements belong to Baltoniodus aff. B. triangularis Lindström, 1955. B. triangularis is the index species used to define the base of the Dapingian Stage (Wang et al. 2009). The Baltoniodus conodont elements from the Faraghan Mountains show minor but constant differences suggesting that Baltoniodus aff. B. triangularis belongs to the genus and can be placed at the base of the Baltoniodus phylogenetic lineage. In South China, the earliest representatives of Baltoniodus appear within the late Floian Oepikodus evae Zone considerably below the FAD of $B$. triangularis. They may represent a separate taxon tentatively identified as Baltoniodus cf. B triangularis (Wang et al. 2005, 2009). It is probable that the Iranian specimens assigned to Baltoniodus aff. $B$. triangularis should have similar or even older age.

Recently, conodont elements conspecific to Baltoniodus aff. B. triangularis have been reported from the lower member of the Rann Formation in the northern Oman Mountains (Fortey et al. 2011), where they co-occur with graptolites that include Baltograptus deflexus (Elles \& Wood, 1901) representative of the varicosus-victoriae zones (mid-Floian-early Dapingian).

Large nongeniculate coniform hyaline elements, comprising approximately $10 \%$ of counted specimens, are assigned to Drepanoistodus sp.

Almost $60 \%$ of counted elements most probably belong to a single taxon representing a new genus and species. Though, because of unusual combination of elements in the apparatus and poor knowledge of the Early Ordovician conodont faunas from the "North Gondwana Domain" (Gutiérrez-Marco et al. 2013), they are left without formal taxonomic designation; while morphology and affinitiy of this taxon require further evaluation.

\section{Chitinozoans}

Chitinozoans are represented in the studied collection by 16 species assigned to 10 genera (Fig. 5, Table 1). They occur throughout the basal interval of the Seyahou Formation, ca $18 \mathrm{~m}$ thick (samples MG10002-MG10008), and 
Figure 5. Floian-lower Katian stratigraphical log from the upper reaches of the Tange-Pashag gorge showing stratigraphical position of palynological samples (MG 10001-MG 10029) distribution of chitinozoans (MG10002 to MG10008, MG10011-10019), brachiopods (MG10002/1, MG KF3b) and conodonts (MG10002/1). Abbreviations: HST - highstand system tract, TST transgressive system tract, $\mathrm{mfs}-$ maximum flooding surface.

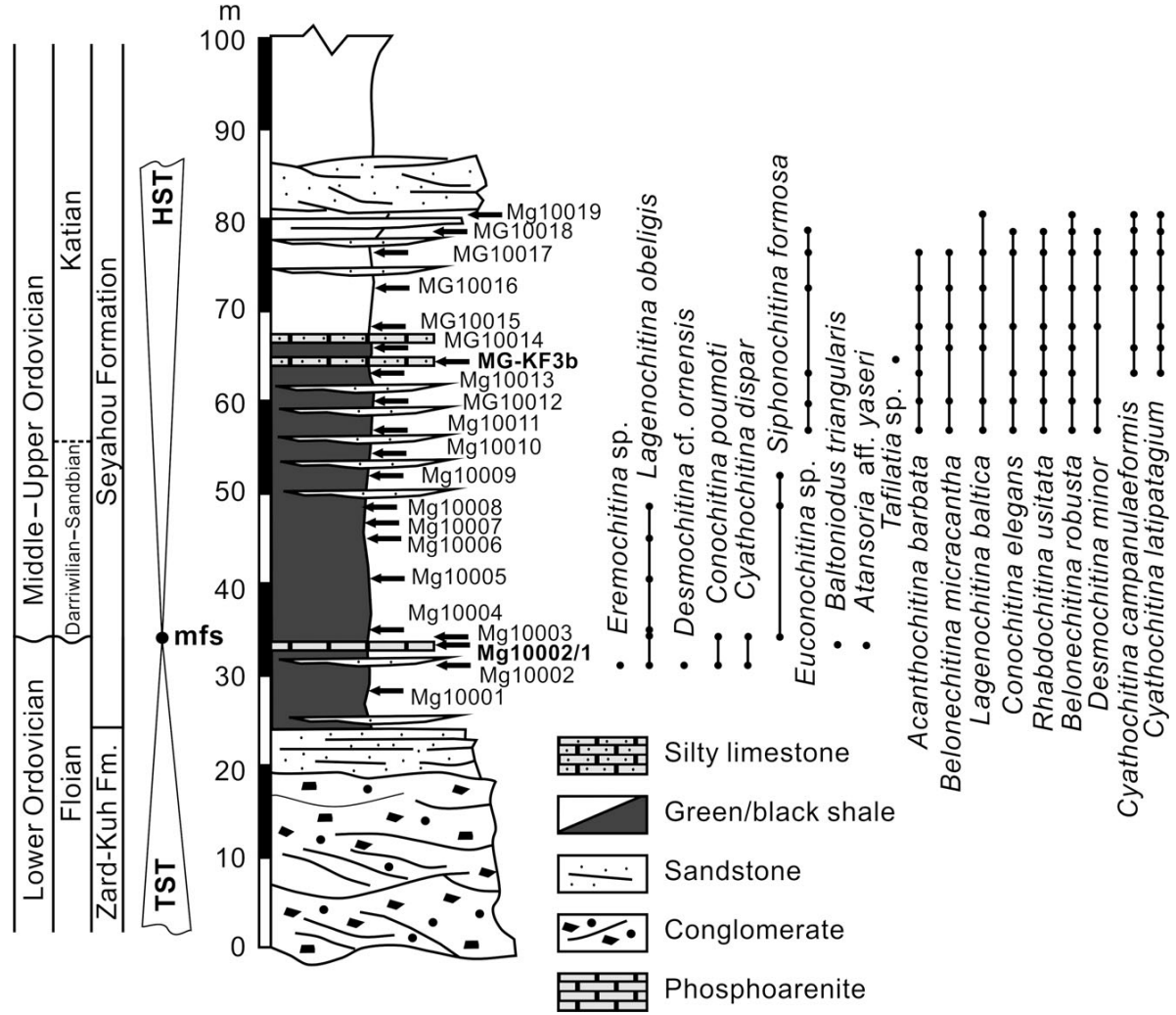

re-appear in the upper part of the studied interval at $c a 8 \mathrm{~m}$ upsequence (samples MG10011-MG10019). Three different assemblages, corresponding to Desmochitina ornensis (sample MG10002), Siphonochitina formosa (samples MG10003-MG10006) and Acanthochitina barbata (samples MG10011-MG10019) biozones have been recognised in the lowermost part of the Syahou Formation.

(1) The lowermost chitinozoan assemblage from sample MG10002 contains Conochitina poumoti Combaz \& Peniguel, 1972; Cyathochitina dispar Benoît \& Taugourdeau, 1961; Desmochitina cf. ornensis Paris, 1981; Eremochitina sp.; Euconochitina sp.; Lagenochitina cf. obeligis Paris, 1981. Desmochitina ornensis is the index species of the eponymous zone erected by Paris (1990) for the Ordovician of high- to mid-latitude peri-Gondwana, the so-called "North Gondwana Domain".

As for other associated taxa, Lagenochitina obeligis is a long-ranging taxon, which appears in the upper part of the Eremochitina brevis Zone and ranges up to the Darriwilian (e.g., Paris 1990, fig. 4; Samuelsson \& Verniers 2000, figs 4, 5). It is used as the index species of the Lagenochitina obeligis Zone in the Lower-Middle Ordovician sequence of the South American sector of Gondwana. According to Grahn (2006), it mainly corresponds to the Dapingian and lower Darriwilian, but the base of the biozone must be likely placed in the upper part of the Floian Stage.

Conochitina poumoti is a cosmopolitan species with diachronous appearences in various continents. The oldest record of the species is from the upper Tremadocian to Floian of the North African Sector of Gondwana (Fezouata Formation, Anti-Atlas, Morocco, Elaouad-Debbaj 1988). In South China (Chen et al. 2009), it ranges from the upper Floian (Oepikodus evae Zone) to the lowermost Darriwilian (Baltoniodus norrlandicus Zone). Conochitina poumoti also occurs in the Dapingian-lower Darriwilian of the Goldwyer and Nita formations, Canning Basin, Western Australia (Combaz \& Peniguel 1972, Winchester-Seeto et al. 2000, Quintavalle \& Playford 2008). According to Chen et al. (2009), the specimens from Laurentia described and figured as Conochitina poumoti by Achab (1982, 1986), Bockelie (1980) and Albani et al. (2001) are most probably not conspecific with the taxon.

Cyathochitina dispar has been reported from the Floian of Southern Europe (Paris 1981), and from the upper Floian-lower Dapingian Abbaye de Villers Formation of the Brabant Massif, Belgium (Samuelsson \& Verniers 2000). In South China, Cyathochitina dispar occurs in the upper part of the Floian Meitan Formation in northern Guizhou (Zhen 1985) and the upper Dapingian-lower Darriwilian part of the Dawan Formation in Yichang (Chen et al. 2009).

The stratigraphic range of Desmochitina ornensis and associated chitinozoans is still a matter of debate. There is indication of an anomalous occurrence of Desmochitina cf. ornensis reported by Hints et al. (2004) from the Tremadocian Paroistodus proteus Zone of North Estonia; however, it was not supported by the description and 
Table 1. The absolute abundance of chitinozoans observed in the samples from the Seyahou Formation. Grey fields indicate barren samples (for sample details see Fig. 3).

\begin{tabular}{|c|c|c|c|c|c|c|c|c|c|c|c|c|c|c|c|c|c|c|c|}
\hline Chitinizoans taxa & 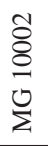 & 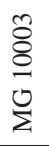 & $\begin{array}{l}\text { t } \\
8 \\
0 \\
\vdots \\
\sum\end{array}$ & 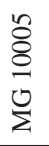 & $\begin{array}{l}8 \\
8 \\
8 \\
0 \\
\vdots \\
\Sigma\end{array}$ & $\begin{array}{l}\hat{8} \\
8 \\
0 \\
\vdots \\
\end{array}$ & 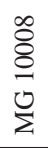 & 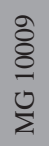 & $\begin{array}{l}\frac{0}{8} \\
8 \\
0 \\
\Sigma\end{array}$ & $\begin{array}{l}\bar{\Xi} \\
8 \\
0 \\
\vdots\end{array}$ & 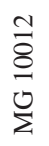 & 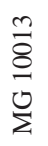 & $\begin{array}{l}\frac{ \pm}{8} \\
\vdots \\
\vdots \\
\Sigma\end{array}$ & $\begin{array}{l}\frac{n}{8} \\
0 \\
0 \\
\Sigma\end{array}$ & $\begin{array}{l}0 \\
\frac{1}{8} \\
0 \\
0 \\
\Sigma\end{array}$ & $\begin{array}{l}\frac{N}{8} \\
\frac{0}{2}\end{array}$ & $\frac{\frac{\infty}{8}}{\frac{0}{2}}$ & $\frac{\frac{9}{8}}{\frac{0}{2}}$ & 풍 \\
\hline Eremochitina $\mathrm{cf}$. brevis & 3 & & & & & & & & & & & & & & & & & & 3 \\
\hline Desmochitina cf. ornensis & 2 & & & & & & & & & & & & & & & & & & 2 \\
\hline Cyathochitina dispar & 2 & 1 & & & & & & & & & & & & & & & & & 3 \\
\hline Conochitina poumoti & 2 & 1 & & & & & & & & & & & & & & & & & 3 \\
\hline Lagenochitina $\mathrm{cf}$. obeligis & 2 & 2 & 3 & 1 & 2 & 3 & & & & & & & & & & & & & 13 \\
\hline Siphonochitina formosa & 0 & 3 & 0 & 0 & 2 & 0 & 3 & & & & & & & & & & & & 8 \\
\hline Conochitina elegans & & & & & & & & & & 1 & 1 & 2 & 0 & 0 & 5 & 4 & 1 & & 19 \\
\hline Euconochitina sp. & & & & & & & & & & 25 & 10 & 4 & 0 & 0 & 3 & 8 & 2 & & 52 \\
\hline Rhabdochitina usitata & & & & & & & & & & 2 & 2 & 3 & 2 & 4 & 2 & 8 & 2 & & 25 \\
\hline Acanthochitina barbata & & & & & & & & & & 4 & 2 & 2 & 3 & 2 & 5 & 4 & & & 22 \\
\hline Belonechitina robusta & & & & & & & & & & 2 & 7 & 2 & 3 & 12 & 5 & 9 & 1 & 1 & 42 \\
\hline Desmochitina minor & & & & & & & & & & 2 & 4 & 0 & 0 & 3 & 2 & 5 & 1 & & 17 \\
\hline Belonechitina micracantha & & & & & & & & & & 1 & 4 & 0 & 7 & 6 & 5 & 3 & & & 26 \\
\hline Lagenochitina baltica & & & & & & & & & & 3 & 2 & 0 & 4 & 5 & 3 & 2 & 0 & 1 & 20 \\
\hline Cyathochitina campanulaeformis & & & & & & & & & & & & 3 & 4 & 0 & 15 & 9 & 1 & 1 & 33 \\
\hline Cyathochitina latipatagium & & & & & & & & & & & & 2 & 1 & 4 & 5 & 8 & 6 & 5 & 31 \\
\hline
\end{tabular}

illustration of the specimens. In the "North Gondwana Domain", chitinozoans of the ornensis Zone are often absent (Paris et al. 2007b, text-fig. 2; Videt et al. 2010, Gutiérrez-Marco et al. 2013) and its chronostratigraphic setting is interpolated between the top of the widespread Armorican Quartzite, dated as mid-Florian by means of chitinozoans of the Eremochitina brevis Zone, and the occurrence of pendent didymograptids (Darriwilian 2) in overlying shales. This ambiguous situation led to common modifications of the Dapingian chronostratigraphic subdivision, from considering a single ornensis Zone placed in the "upper Dapingian" (Paris in Webby et al. 2004, Paris et al. 2007b), followed by a "lower Dapingian" ornensis Zone and an "upper Dapingian" henryi Zone (Paris in Chen et al. 2009), to an essentially "upper Dapingian" combination of both biozones (Videt et al. 2010; for further discussion, see Gutiérrez-Marco et al. 2013). The biostratigraphic data reported above do not contradict a possible late Floian age of the chitinozoan assemblage from sample MG10002.

(2) The second assemblage (sample MG10003, MG10006 and MG10008) is characterised by the occurrence of Siphonochitina formosa Jenkins, 1967 (Fig. 5). This is the index-species of its Darriwilian eponymous zone, which is widely traced across the "North Gondwana Domain" (Paris 1990). This species is also documented from the Hanadir Member (lower part of the Qasim Formation; Al-Hajri 1995, Paris et al. 2000), where it occurs in core samples together with graptolite "Didymograptus murchisoni" (= D. artus) characteristic of the mid-Dar- riwilian. Another associated taxa in the sample MG10003 are Conochitina poumoti, Cyathochitina dispar and Lagenochitina cf. obeligis. The latter occurs also in samples MG10004-MG10007.

(3) The third fossiliferous assemblage (Fig. 5) is characterised by the occurrence of Acanthochitina barbata (Eisenack, 1931), which has the first documented occurrence in sample MG10011. A. barbata is the index species of the fourth chitinozoan zone of the Katian Stage in the "North Gondwana Domain" (Webby et al. 2004, fig. 2.2; Paris in Loi et al. 2010). The list of associated chitinozoan taxa includes Belonechitina robusta (Eisenack, 1959), Belonechitina micracantha (Eisenack, 1931), Conochitina elegans Eisenack, 1931, Desmochitina minor Eisenack, 1931, Lagenochitina baltica Eisenack, 1931, and Rhabdochitina usitata Jenkins, 1967. Two more taxa, including Cyathochitina campanulaeformis (Eisenack, 1931) and Cyathochitina latipatagium Jenkins, 1969, are added to the assemblage from the sample MG10013.

\section{Acritarchs}

Acritarchs proved significantly more common than chitinozoans in the studied samples (Fig. 6, Table 2). A total of 52 acritarch species assigned to 26 genera have been identified. Seven succeeding acritarch assemblages different in diversity and taxonomic composition can be recognised through the studied sequence. 
(1) The lowermost assemblage from sample MG10001 is dominated in abundance by two species: Tectitheca additionalis Burmann, 1968 (Fig. 7I) and Polygonium gracile Vavrdová, 1966. T. additionalis is the most abundant taxon in the assemblage. It was originally described from the Middle Ordovician of Cis, Saharan Morocco (Cramer \& Díez 1977). According to Yan et al. (2005), in South China T. additionalis and Striatotheca transformata are confined to the late Floian $C$. deflexus and A. suecicus graptolite zones; in other parts of Gondwana, it ranges up to the lower Darriwilian. In north-western Argentina, T. additionalis occurs in the lower part of the Darriwilian Capillas Formation (Rubinstein et al. 2011). By contrast, Polygonium gracile, which has the second frequency in the sample, is a long-ranging taxon known from the Furongian to the Middle Ordovician (Brocke 1998, Cramer \& Díez 1977, Vecoli \& Le Hérissé 2004).

There are also several species with their First Appearance Datum (FAD) in the upper Floian, including Aureotesta clathrata simplex (Cramer et al., 1974) Brocke et al., 1998 (Fig. 7G), which ranges from the upper brevis Zone to the top of the Darriwilian (Vecoli \& Le Hérissé 2004), whereas Coryphidium bohemicum Vavrdová, 1972 (Fig. 7D) and Striatotheca principalis parva Burmann, 1970 (Fig. 7H) were reported from the A. suecicus and C. deflexus zones of South China (e.g. Li et al. 2004).

Three acritarch taxa have been previously documented from the Middle Ordovician, with FAD at the Desmochitina ornensis Zone or the overlying Belonechitina henryi Zone (Vecoli \& Le Hérissé 2004): these are Acanthodiacrodium tadlense Cramer \& Díez, 1977; Acanthodiacrodium vavrdovae Cramer \& Díez, 1977 (Fig. 7J) and Barakella filex Cramer \& Díez, 1977. In addition to the reported taxa, the assemblage contains numerous long-ranging species, which appeared already in the upper Tremadocian to lower Floian (Vecoli \& Le Hérissé 2004), including Acanthodiacrodium ex. gr. costatum Burmann, 1968; Acanthodiacrodium uniforme Burmann, 1968; Arbuscludium filamentosum (Vavrdová, 1965) Fatka \& Brocke, 1999; Arkonia sp.; Coryphidium bohemicum Vavrdová, 1972; Coryphidium milida Cramer \& Diez, 1976; Coryphidium? sp.; Cristallinium dentatum (Vavrdová) Martin, 1984; Cymatiogalea granulata Vavrdová, 1966; Dactylofusa velifera (Cocchio) Albani, 1989; Pirea sinensis Li, 1987; Picostella perforata Cramer et al., 1974; Picostella turgida Yin, Di Milia \& Tongiorgi, 1998; Stelliferidium striatulum (Vavrdová) Deunff et al., 1974; Striatotheca principalis parva Burmann, 1970; Striatotheca transformata Burmann, 1970; Tectitheca additionalis Burmann, 1968 and some taxa reworked from underlying strata, including Vulcanisphaera africana Deunff, 1961, Caldariola glabra (Martin, 1972) Molyneux, 1988, Cymatiogalea boulouardi Deunff, 1961, Cymatiogalea messaoudensis Jardiné et al., 1974 and Cymatiogalea velifera (Downie, 1959) Martin, 1969.
(2) The second assemblage (sample MG10002) contains a significant number of acritarch taxa that were already present in the sample MG10001. In addition, some newly appeared acritarch species, including Pirea dubia Vavrdová, 1972; Rhopaliophora palmata (Combaz \& Peniguel) Playford \& Martin, 1984; Veryhachium lairdii (Deflandre) Deunff, 1959 ex Downie, 1959; and Veryhachium trispinosum (Eisenack, 1938) Deunff, 1959 ex Downie, 1959 are of a long range and they are known elsewhere already from the Tremadocian or Floian (Tongiorgi et al. 1995; Raevskaya 1999; Ghavidel-Syooki 2000, 2001; Vecoli \& Le Hérissé 2004).

Barakella rara (Lu, 1987) Tongiorgi, Yin \& Di Milia, 1995 is reported by Vecoli \& Le Hérissé (2004, fig. 5) as appearing in the Dapingian, but in South China it was undoubtedly documented from the upper Floian Oepikodus evae Biozone (Tongiorgi et al. 1995).

The presence of Vogtlandia flosmaris Burmann, 1970 and Pterospermella colbathii Vavrdová, 1990 looks somewhat problematic, because they are not reported elsewhere in deposits older than the Darriwilian (Fensome et al. 1990; Vecoli \& Le Hérissé 2004, fig. 5)

(3) The acritarch assemblage from sample MG10003 shows close resemblance to the assemblage from MG10002 both in taxonomic diversity and relative abundance (Table. 2). Their only difference is the presense of Veryhachium symmetricum (Lu, 1987) Tongiorgi, Yin \& Di Milia, 1995 and Rhopaliophora pilata (Combaz \& Peniguel, 1972) Playford \& Martin, 1984. Both taxa have been reported elsewhere from the Floian (Tongiorgi et al. 1995, Raevskaya 1999) and the only indication of a Darriwilian age is their association with Pterospermella colbathii Vavrdová, 1990 and association with the chitinozoan Siphonochitina formosa.

(4) Acritarch diversity declines significantly in samples MG10004 and MG10005 (Fig. 6), which contain only transitional taxa, including Acanthodiacrodium vavrdovae, Aureotesta clathrata var. simplex, Coryphidium bohemicum, Polygonium gracile, Tectitheca additionalis and Veryhachium trispinosum, probably due to environmental constraints.

(5) Samples MG10006 and MG10007 are characterised by the co-occurrence of Aremoricanium rigaudiae Deunff, 1955 (Fig. 7E) and Dicrodiacrodium ancoriforme (Burmann, 1968) Servais et al., 1996 (Fig. 7F). Both taxa are often considered as characteristic of the Darriwilian (Vecoli et al. 1999, Paris et al. 2007a), although a recent revision by Vecoli \& Le Hérissé (2004, fig. 5) clearly indicated that their FAD occurred as early as the lower Floian, thus they are considered here as biostratigraphically uninformative.

(6) Samples MG10008 and MG10009 contain a low diversity acritarch association that comprises a few transitional taxa, including Acanthodiacrodium vavrdovae, 
Arbusculidium filamentosum, Aureotesta clathrata var. simplex, Coryphidium bohemicum, Dactylofusa velifera, Dicrodiacrodium ancoriforme, Pirea sinensis, Polygonium gracile, Tectitheca additionalis, Veryhachium ex. gr. lairdii and Veryhachium ex. gr. trispinosum. The only biostratigraphically informative species, which appears in sample MG10008, is Ordovicidum elegantulum Tappan \& Loeblich, 1971 (Fig. 8E). It can be considered as the indicator of the base of the Upper Ordovician Series (Jachowicz 1995).

(7) Other typical Late Ordovician acritarchs (Assemblage 3) occur only in the uppermost part of the sequence (samples MG10011-MG10019). In particular, Aremoricanium syringosagis Loeblich \& MacAdam, 1971 and Villosacapsula setosapellicula (Loeblich, 1970) Loeblich \& Tappan, 1976 (Fig. 8F) appear for the first time in sample MG10011 (Fig. 6, Table 2) together with chitinozoans characteristic of the Acanthochitina barbata Biozone. Orthosphaeridium spp. (Fig. 8H-J) first occur in sample MG10012 in association with a number of transitional species, including Aremoricanium rigaudae, Polygonium gracile and Veryhachium ex. gr. trispinosum. Ordovicidum elegantulum is a relatively rare taxon, which occur in low frequencies only in the samples MG10012, MG10015 and MG10017.

\section{Biostratigraphic constraints}

The lower member of the Seyahou Formation, underlying the phosphoritic level, contains Desmochitina cf. ornensis, which is close to the index species of its eponymous zone. Originally, the base of the Desmochitina ornensis Zone was defined in the Domfront Syncline (Armorican Massif, France) at the base of the Pissot Formation, which is separated by a stratigraphical discontinuity from the underlying Armorican Quarzite Formation (Paris 1990). Precise chronostratigraphical position of the base of the ornensis Zone is difficult to define in the "North Gondwana Domain", where its setting is commonly interpolated between fossiliferous strata or simply absent by erosion or non-deposition, which is the case of the central Anti-Atlas (Videt et al. 2010). Dapingian and lower Darrivilian strata are exclusively identified in this domain in a "condensed" sequence, 6-8 $\mathrm{m}$ thick, of some areas of the Armorican Massif (Dabard et al. 2007) and in the Pochico Beds, ca $200 \mathrm{~m}$, of the Central-Iberian Zone in the Iberian Peninsula (Gutiérrez-Marco et al. 2013). As stated above, the ornensis Zone and the stratigraphic ranges of its associated chitinozoans are in need of revision.

The occurrence of the conodont Baltoniodus aff. B. triangularis in the phosphoarenitic sample MG10002/1 (1.5 $\mathrm{m}$ above sample MG10002), which is probably the most primitive representative of the Baltoniodus lineage (see discussion below), provides confident chronostratigraphic constraints for the chitinozoan-based biostratigraphy. Based on the correlations reported above, the phosphoarenitic bed confidently represents the topmost part of the Floian.

The occurrence of Siphonochitina formosa Jenkins, 1967, the index-species of the mid-Darriwilian eponymous chitinozoan zone (sample MG10003), in black shales directly capping the phosphoarenite bed, suggests the presence of a paraconformity capping the lower member of the Seyahou Formation. This stratigraphic gap includes the entire Dapingian and the lower part of the Darriwilian Stage. In addition, conodonts of the phosphorite bed (sample MG10002/1) are latest Early Ordovician in age, which contrasts with the mid-Darriwilian Siphonochitina formosa Zone age (sample MG10003) of the immediate overlying black shales. This suggests the setting of a stratigraphic gap with at least five chitinozoan biozones missing. Correlation with the Ordovician sequence of the Arabian Peninsula suggests that the phosphoritic level that separates the lower and middle members of the Seyahou Formation closely coincides with the base of the Hanadir Member, which is the lowermost unit of the Middle-Upper Ordovician Qasim Formation. The Hanadir Member consists of homogeneous black shales locally punctuated by subsidiary phosphoritic beds at the base (Al-Hajri 1995). The Dapingian-lower Darriwilian interval is incompletely recognised in the "North Gondwana Domain", due to the unidentification of the chitinozoans representative of the ornensis Zone, a contemporaneous gap in central Anti-Atlas, and the presence of similar condensed phosphatic hardgrounds and beds in the Armorican Massif (Dabard et al. 2007).

The setting of the Darriwilian-Sandbian (Middle-Upper Ordovician) boundary in the studied section is poorly constrained due to the absence of biostratigraphically significant taxa; however, it may be close to the first occurrence of the acritarch Ordovicidum elegantulum Tappan \& Loeblich, 1971 (sample MG10008). A sequence of appearences of several indicative acritarch taxa can be also used to identify its approximate position. In particular, the co-occurrence of Dicrodiacrodium ancoriforme and Ordovicidium elegantulum (sample MG10008) may suggest a late Darriwilian to early Sandbian (up to Lagenochitina deunffi Zone) age. Other typical Late Ordovician taxa, such as Villosacapsula setosapellicula (sample MG10011) and Orthosphaeridium spp. (sample MG10012) appear upsection within the stratigraphic interval which is dated as Katian by their associated chitinozoan species (Table 2).

The beginning of the Katian can be placed somewhat below the FAD of Acanthochitina barbata and Belonechitina robusta (sample MG10011). Acanthochitina barbata is the index species of the eponymous mid Katian chitinozoan zone in the "North Gondwana Domain" (Paris 
Table 2. The acritarch assemblages and absolute abundance of acritarch taxa observed in the samples from the Seyahou Formation (for sample details see Figs 4, 5).

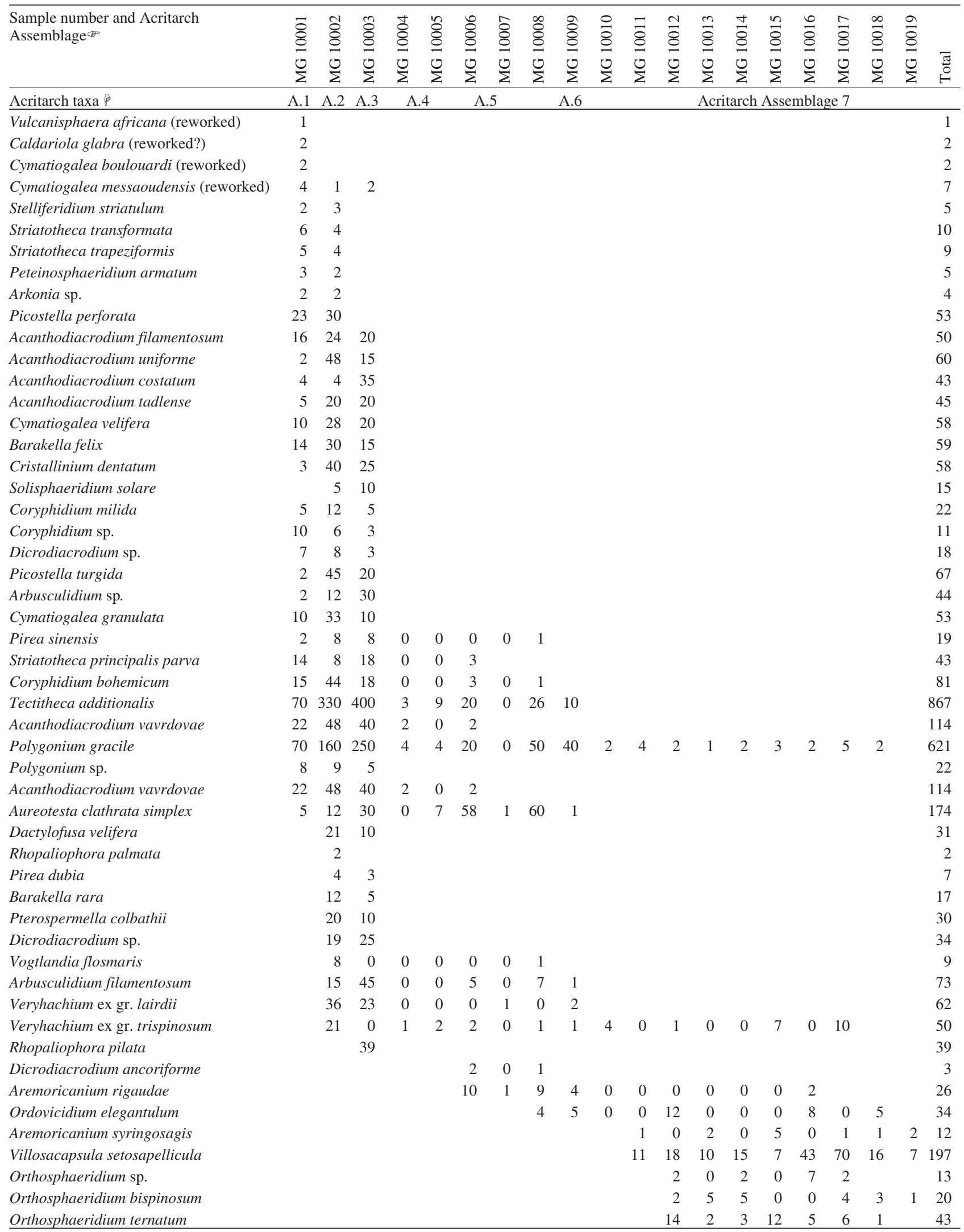




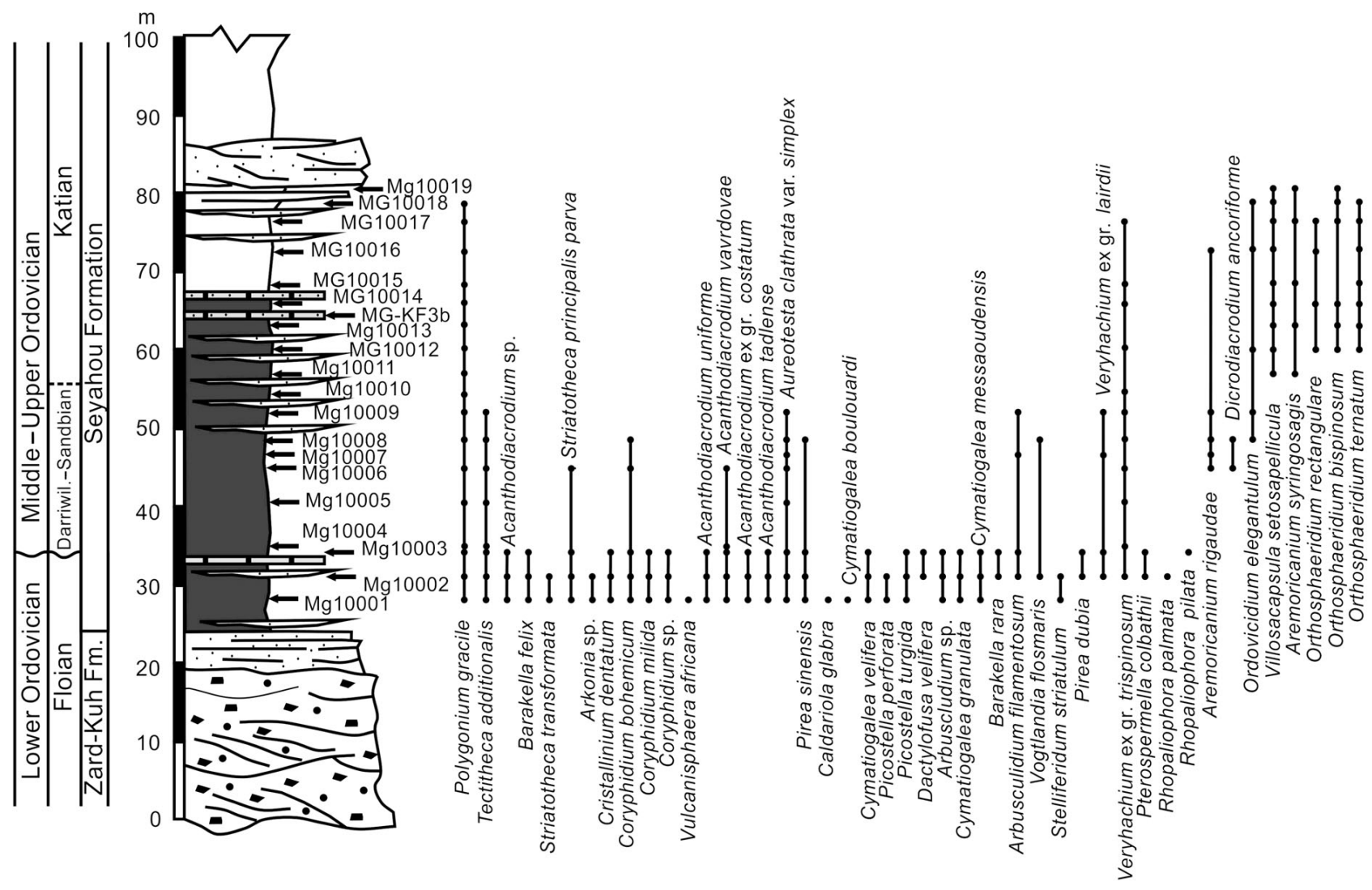

Figure 6. Floian-lower Katian stratigraphical log from the upper reaches of the Tange-Pashag gorge showing stratigraphical position of palynological samples and distribution of acritarchs.

et al. 2007b, Paris in Loi et al. 2010). The earliest Katian Jenkinochitina tanvillensis Zone was not yet identified in the sequence. In the Arabian Peninsula, there is no record of Belonechitina robusta; however, Acanthochitina barbata occurs in the lower part of the regional Armoricochitina aff. fistulosa Zone (Al-Hajri 1995, fig. 4). The Ra'an Member of the Qasim Formation also contains Jenkinochitina tanvillensis (Paris in Robardet et al., 1972), Calpichitina lenticularis (Bouché, 1965) and Belonechitina micracantha (Eisenack, 1931), and therefore can be correlated with the interval from sample MG10011 to sample MG10019 in the Faraghan Mountains.

\section{Comparison with neighbouring areas}

The presence of Cruziana ichnofossils is common in Lower Ordovician strata of the Arabian margin of Gondwana. In the Arabian Peninsula, both the Cruziana Shale and Sajir members of the Saq Formation comprise siliciclastic fluvio-marine deposits rich in these trace fossils (ElKhayal \& Romano 1988; Fig. 2). In the Oman Mountains (UAE), the lower member of the Rann Formation is also rife of Cruziana ichnofossils. The member contains trilobites, such as Neseuretus cf. arenosus Dean, 1967 and Tai- hungshania cf. miqueli (Bergeron, 1893) suggesting an early Floian age, conodonts of the Baltoniodus genus (considered here as conspecific to Baltoniodus aff. B. triangularis from the lowermost Seyahou Formation), and graptolites characteristic of the varicosus-victoriae zones suggesting a mid-Floian to early Dapingian age (Rickards et al. 2010).

Recent stratigraphic studies have revealed the onset of numerous Ordovician gaps in the Arabian Peninsula (e.g. Molyneux et al. 2006, Rickards et al. 2010, Fortey et al. 2011). The Dapingian-lower Darriwilian gap reported in the phospharenite that caps the lower member of the Seyahou Formation is somewhat correlatable with similar gaps (although of different time span) of UAE, Oman, Saudi Arabia and the Alborz Region of Iran (Fig. 2).

In the UAE, biostratigraphical data on the the Rann Formation from Ras Al Khaimah (Fortey et al. 2011) suggest the presence of a considerable stratigraphic gap separating Lower and Middle Ordovician strata (Fig. 2). The Ayim Member contains a late Darriwilian conodont assemblage suggesting recognition of the late Pygodus serra conodont Zone (Fortey et al. 2011). In Oman, the Dapingian-Darriwilian transition is absent due to the onset of a gap marking the Ghudum/Saih Nihayda contact (Molyneux et al. 2006; Fig. 2). 


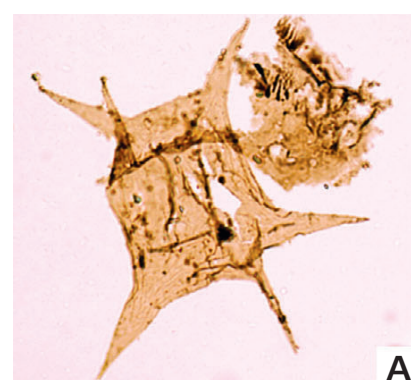

A
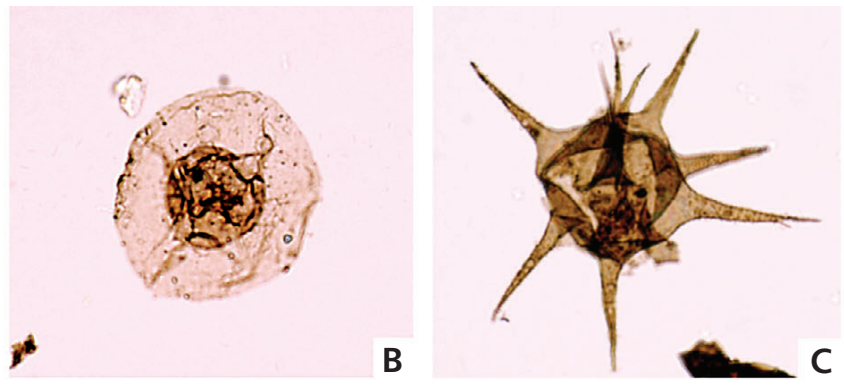

c
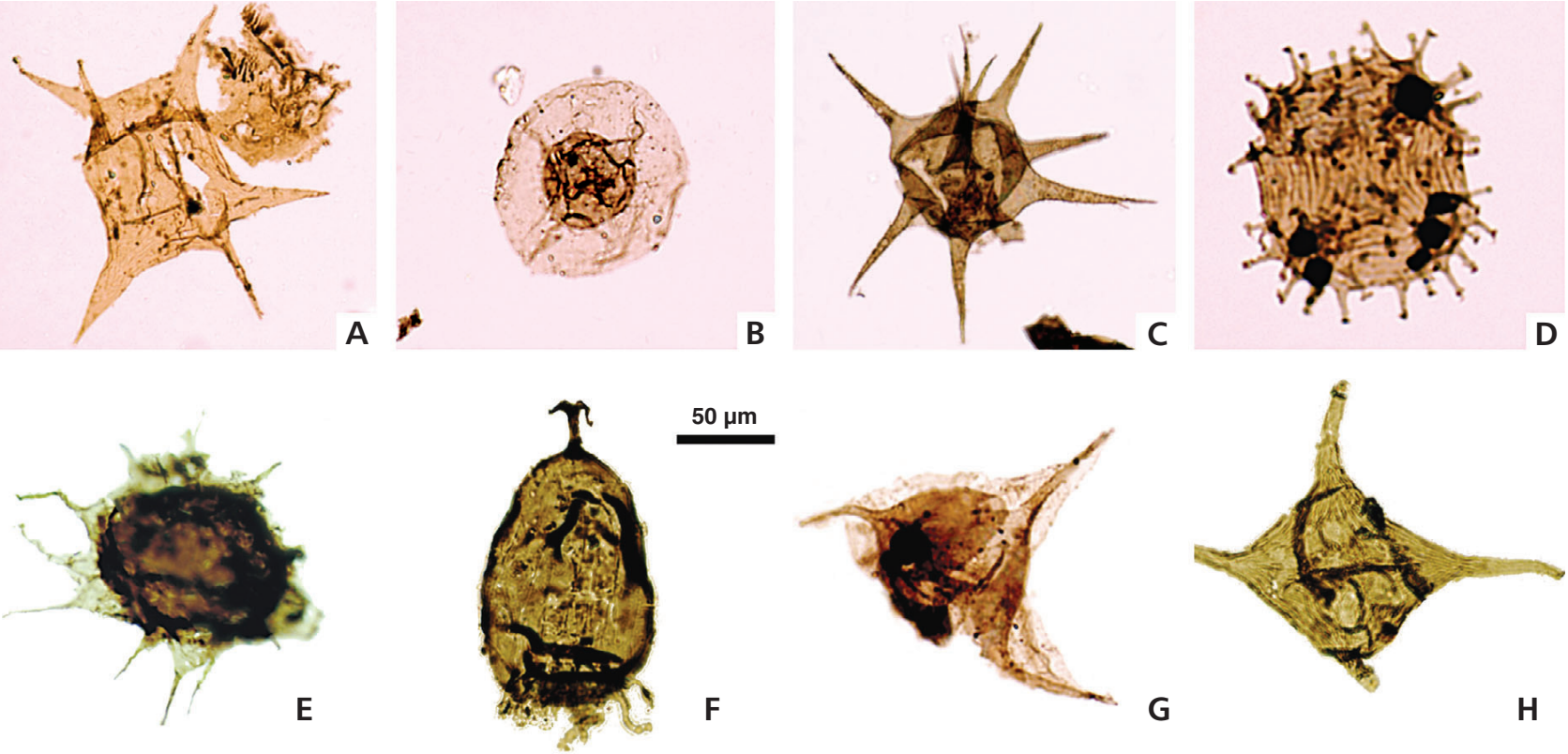

G

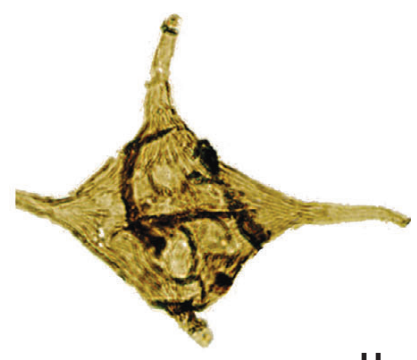

H
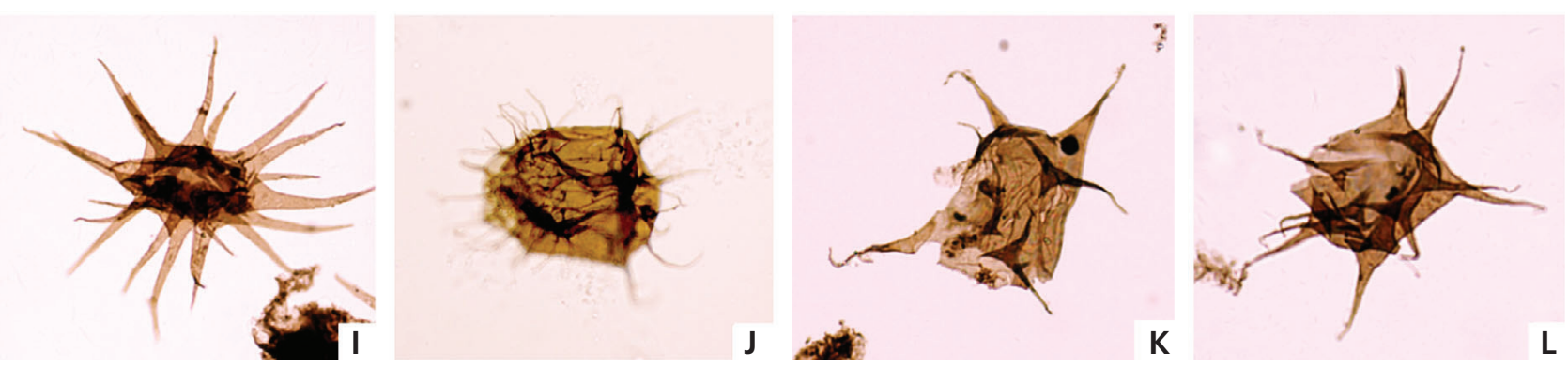

Figure 7. A - Striatotheca transformata Burmann, 1970, NIOC/MG10001/IOOC slides 1-2, sample MG10001. • B - Pterospermella colbathii Vavrdová, 1990, NIOC/MG10003/IOOC slides 1-3, sample MG10003. - C - Barakella rara (Li) emend. Tongiorgi, Yin \& Di, 1995, NIOC/MG10002/IOOC slides 1-2, sample MG10002. • D - Coryphidium bohemicum Vavrdová, 1972, NIOC/MG10002/IOOC slides 1-2, sample MG10002. • E - Aremoricanium rigaudiae Deunff, 1955, NIOC/MG10006/IOOC slides 1-2, sample MG10006. • F - Dicrodiacrodium ancoriforme Burmann, 1968, NIOC/MG10006/IOOC slides 1-2, sample MG10006. • G - Aureotesta clathrata simplex (Cramer et al., 1974) emend. Brocke et al., 1998, NIOC/MG10002/IOOC slides 1-2, sample MG10002. • H - Striatotheca principalis parva Burman, 1970, NIOC/MG10003/IOOC slides 1-2, sample MG10003. • I - Tectitheca additionalis Burmann, 1968, NIOC/MG10003/IOOC slides 1-2, sample MG10003. • J - Acanthodiacrodium vavrdovae Cramer \& Díez, 1977, NIOC/MG10003/IOOC slides 1-2, sample MG10003. • K - Barakella felix Cramer \& Díez, 1977, NIOC/MG10002/IOOC slides 1-2, sample MG10002. • L - Acanthodiacrodium tadlaense Cramer \& Díez, 1977, NIOC/MG10002/IOOC slides 1-2, sample MG10002. All scale bars are $50 \mu \mathrm{m}$.

In the central part of the Arabian Peninsula, there is uncertainty in the character of the Saq/Qasim contact: e.g., Senalp \& Al-Duaiji (2001, p. 241) considered as conformable based on the study of core samples (well QSIM-801), although Le Hérissé et al. (2007) mentioned a gradational and apparently conformable transition. In addition, Vaslet $(1989,1990)$ pointed out the presence of phosphatic bioclastic conglomerates in the lowermost part of the Hanadir Member (lower part of the Qasim Formation), which suggests the record of one or several erosive discontinuities. In addition, Al-Hajri (1995) introduced the Velatachitina veligera Zone in the upper part of the Saq Formation at the KAHF-1 well, which was considered as a local equivalent of the earliest Floian
Desmochitina ornensis Zone. Though, a recognition of the Desmochitina bulla Zone in the lowermost part of the Hanadir Member looks highly questionable, as well as chitinozoans characteristic of this biozone co-occur with Siphonochitina formosa (Al-Hajri, 1995) suggesting the onset of stratigraphic discontinuities and the extensive reworking of Dapingian-early Darriwilian chitinozoans from underlying sediments is suggested by several authors (see diagram in Fig. 2). This correlation also suggests that the lower part of the Seyahou Formation, dominated by green and secondary black shales is extremely condensed by comparison with the Lower-Middle Ordovician succession of the Arabian Peninsula. In the Faraghan Mountains, the stratigraphical equivalent of the 
Hanadir and Kahfah members of the Qasim Formation does not exceed $25 \mathrm{~m}$ in thickness.

All these data clearly suggest that the Saq/Qasim lithostratigraphic contact is also paraconformable, but there are not enough biostratigraphical constraints to define the time span involved in the gap. Data from the Zagros Ranges and the Arabian Peninsula suggest that the base of Siphonochitina formosa Zone, which corresponds to the base of the Hanadir Member and the base of the middle Seyahou Member post-dates the onset of phosphogenic processes related to widespread condensation of regional importance. In addition, the Siphonochitina formosa Zone coincides with a major third-order flooding surface recognized in North Africa (Videt et al. 2010, fig. 8), apparently synchronous with Nielsen's (2004) Helskjer Drowning Event and the associated mid-Darriwilian Positive Carbon Isotope Excursion in Baltoscandia (Ainsaar et al. 2010), and with a distinct transgression and proliferation of the Saucrorthis Brachiopod Association in the Alborz Mountains of Iran, which occurred at the Lenodus pseudoplanus Zone (Ghobadi Pour et al. 2011).

\section{Systematic palaeontology}

The illustrated and described brachiopods and conodonts are housed in the National Museum of Wales, Cardiff (NMW) and in the Central Geological Research and Exploration Tschernyshev Museum, St Petersburg (CNIGR), respectively. Palynomorph slides are housed in the palaeontological collections of the Iranian Offshore Oil Company (IOOC) under repository numbers NIOC/IOOC/MG10001 to NIOC/IOOC/MG10019.

\section{Brachiopods (L.E. Popov \& M. Ghobadi Pour)}

Abbreviations. $-\mathrm{W}, \mathrm{L}, \mathrm{T}=$ maximum width, length, thickness of the shell; $\mathrm{Lv}, \mathrm{Ld}=$ maximum length of ventral and dorsal valve.

Class Lingulata Gorjansky \& Popov, 1985

Order Lingulida Waagen, 1883

Superfamily Linguloidea Menke, 1828

Family Obolidae King, 1846

\section{Genus Atansoria Popov, 2000}

Type species. - Atansoria concava Popov, 2000; Ordovician, lower Katian (Dulankara Regional Stage), Mayatas Formation, north-central Kazakhstan.

Remarks. - Previously Atansoria was known only from the Upper Ordovician (Katian) of north-eastern Central Ka- zakhstan and New South Wales, Australia (Popov 2000). It is distinct in having a concave dorsal valve, which is unknown in other obolide genera, but morphology of the ventral valve is unknown.

\section{Atansoria yaseri sp. nov.}

Figure 9

Derivation of name. - After Yaser Sheikhan in appreciation of his kind assistance during fieldworks in the Zagros Range.

Holotype. - NMW 2011.10G.128 ( $\mathrm{Lv}=0.76, \mathrm{Ld}=0.72$, $\mathrm{W}=76$ ), conjoined valves, Lower Ordovician, Floian, Seyahou Formation, sample MG10002/1, Faraghan Mountains, Zagros Ranges, Iran.

Paratypes. - NMW 2011.10G.116 $(\mathrm{Ld}=0.54, \mathrm{~W}=0.62)$, $117(\mathrm{Lv}=0.50, \mathrm{~W}=0.46), 118(\mathrm{Lv}=0.50, \mathrm{~W}=0.54), 119$ $(\mathrm{Lv}=0.46, \mathrm{Ld}=0.44, \mathrm{~W}=0.46), 120(\mathrm{Lv}=0.58, \mathrm{~T}=0.19)$, $122(\mathrm{Lv}=0.52, \mathrm{~W}=0.52), 123$, conjoined valves; NMW 2011.10G.121, 124-127, ventral valves. Total eight conjoined valves and five ventral valves. Locality and age as for holotype.

Diagnosis. - Concavoconvex shell almost circular in outline and about one third as thick as long. Ventral valve about $93-109 \%$ as long as wide and ornamented with regular concentric rugellae; strongly convex in a sagittal profile with maximum depth at about $30 \%$ of sagittal valve length from the umbo. Dorsal valve slightly shorter than ventral valve, smooth, gently concave with swollen umbonal area.

Description. - Shell concavoconvex, almost circular in outline, about $93-109 \%$ as long as wide and about one third as thick as long. Anterior commissure rectimarginate. Lateral profile of the ventral valve strongly convex with maximum height at about $30 \%$ valve length from the umbo. Dorsal valve gently concave with a slightly swollen umbonal area. Pseudointerarea absent in both valves. Ventral valve ornamented with regular concentric rugellae with gradually increasing interspaces from the umbo to the anterior margin with 10 rugellae at $100-200 \mu \mathrm{m}$ from the umbo and 5 rugellae at $400-500 \mu \mathrm{m}$ from the umbo. Dorsal valve smooth with regular concentric fila. Larval shell small, up to $75 \mu \mathrm{m}$ across, smooth, with a small posteromedian mound probably corresponding to the metamorphic protegulum. Ventral interior lacking distinctive features; dorsal interior unknown.

Remarks. - Atansoria yaseri sp. nov. differs from the type species Atansoria concava Popov in having more than twice smaller shell with a thin, weakly convex dorsal valve and a swollen dorsal umbonal area. Morphology of the ventral valve in the type species remains unknown. 

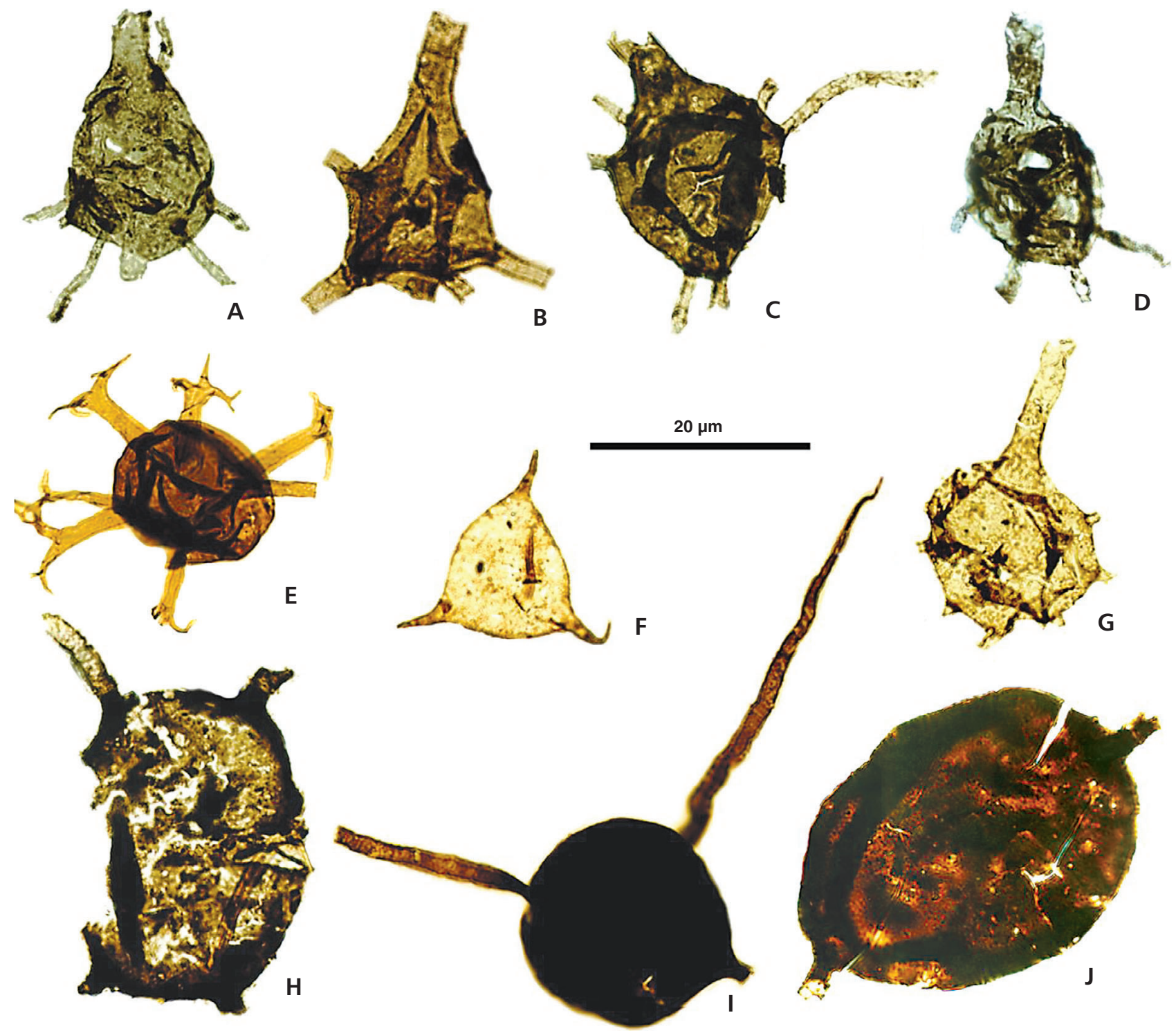

Figure 8. A-D, G - Aremoricanium syringosagis Loeblich \& MacAdam, 1971, NIOC/MG10011/IOOC/ slides 1-2, sample MG10011. - E - Ordovicidium elegantulum Tappan \& Loeblich, 1971, NIOC/MG10009/IOOC/ slide 1, sample MG10009. • F - Villosacapsula setosapellicula (Loeblich, 1970) Loeblich \& Tappan, 1976, NIOC/MG10011/IOOC/ slide 1, sample M10011. • H - Orthosphaeridium sp., NIOC/MG10012/IOOC/ slide 1, sample MG10012. • I - Orthosphaeridium ternatum (Burman, 1970) Eisenack, Cramer \& Díez, 1973, NIOC/MG10014/IOOC/ slide 3, sample MG10012. • J - Orthosphaeridium bispinosum Turner, 1984, NIOC/MG10013/IOOC/ slide 2, sample MG10013. All scale bars are $50 \mu \mathrm{m}$.

\section{Conodonts (T.Y. Tolmacheva)}

\section{Genus Baltoniodus Lindström, 1971}

Type species. - Prioniodus navis Lindström, 1955; Middle Ordovician, Dapingian, Baltoscandia.

Baltoniodus aff. B. triangularis Lindström, 1955

Figure 10A-J

2011 Baltoniodus sp.; Fortey et al., p. 136, pl. 3, figs 1-6.
Material. - More than 300 isolated elements, sample MG10002/1. Lower Ordovician, Floian, Seyahou Formation, Lower Member.

Remarks. - The $P$ elements usually have denticulate posterior, adenticulate anterior and generally adenticulate lateral processes. Only few $\mathrm{Pa}$ elements bear one or two small denticles on distal part of lateral process. $S d$ elements are trapezoid and bear small, more or less confluent denticles on all processes. Although $M$ elements are slightly variable in morphology; however most of them have relatively short 
posterior extension of the base and rudimentary denticles on the upper anterior margin. In all these features the Iranian specimens bear distinct similarities to the conodonts from the Rann Formation Lower Member of United Arab Emirates, briefly described and illustrated by Fortey et al. (2011) as Baltoniodus sp. and they are considered here as conspecific.

Both the generic and species assignment of elements in the collection is problematic and needs further comments. Baltoniodus triangularis and especially its derived predecesor from China Baltoniodus cf. B. triangularis (Wang et al. 2005, 2009) are very similar morphologically to contemporaneous early species of Trapezognathus. Representatives of both lineages occur together in Baltoscandia and South China which sometimes make difficult a generic assignment of broken and juvenile elements. This problem was evident in the description of Baltoniodus? triangularis from the Horns Udde section from northern part of Öland (Sweden) with a question mark (Bagnoli \& Stouge 1997). After the revision of the topotype material from Sweden (Bergström \& Löfgren 2009) the generic identity of the Swedish and Chinese Baltoniodus triangularis and Baltoniodus cf. B. triangularis was considered undoubted (Wang et al. 2009).

It was reported that the main difference of Baltoniodus triangularis and its ancestor Baltoniodus cf. B. triangularis is the lack in the latter of confluent denticles on the anterior process of the $\mathrm{Pb}$ element of the latter species (Stouge in Wang et al. 2005). Younger representatives of Baltoniodus lineage [e.g. Baltoniodus navis (Lindström, 1955) and Baltoniodus variabilis (Bergström, 1962)] exhibit further development of denticulation on $P$ element processes, strong reduction of basal sheath and increase of length of free processes.

In turn Baltoniodus cf. B. triangularis differ from Trapezognathus diprion (Lindström, 1955) in the development of free denticles on the anterior and posterior processes of the $P$ element (Wang et al. 2005). There is also a subtle difference between Baltoniodus and Trapezognathus in $M$ and $S$ elements (Stouge \& Bagnoli 1990). The cusps of the latter form an angle of $90^{\circ}$ with the upper margin of the base, whereas this angle is generally less in Baltoniodus. Cusp of $S$ elements of Baltoniodus is significantly longer than that of Trapezognathus.

The Iranian elements are simpler than Baltoniodus cf. $B$ triangularis in the morphology of $P$ elements which resemble corresponding elements of Trapezognathus more than Baltoniodus. However, the assignment of them to the most primitive and ancestor species of the Baltoniodus line- age (Baltoniodus aff. B. triangularis) is based on morphological characters of all element types: long cusps of $S d$ elements that generally have regular denticulation of all processes, reclined long cusps of $M$ elements and presence of denticles on posterior processes of $P$ elements.

In addition, Baltoniodus aff. $B$. triangularis is a similar to Barrandegnathus Stouge, 2005 based on a single, morphologically primitive single species B. bohemicus (Dzik, 1983). This species was originally described from the Klabava Formation in Bohemia, but was subsequently found in the uppermost part of the Volkhov Stage of Sweden (Bornholm and western Scania) (Stouge 2005). Despite the shared similarity in morphology of $P$ elements with the earliest representatives of Baltoniodus the former genus differs in the absence of sheath and the development of free processes in $S$ elements.

\section{Genus Drepanoistodus Lindström, 1971}

Type species. - Oistodus forceps Lindström, 1955, Lower Ordovician, Floian, Billingen Regional Stage, Sweden.

\section{Drepanoistodus sp. Figure 10K-M}

Material. - About 100 isolated elements, sample MG10002/1. Lower Ordovician, Floian, Seyahou Formation, Lower Member.

Remarks. - This unnamed Drepanoistodus species includes large hyaline coniform geniculate and nongeniculate elements. Geniculate elements have relatively short posterior extension of the base and smooth, convex outer and inner lateral sides (Fig. 10K). Few elements have wide rounded costae on the outer side. Sa elements are suberectiform with smooth lateral sides, whereas the other nongeniculate elements bear from one to three lateral sharp costae.

The elements of Drepanoistodus sp. most resemble Drepanoistodus costatus (Abaimova, 1971) originally described from the Siberian Platform as they are hyaline, large and some morphotypes have costate lateral sides. Morphologically similar elements, identified as Drepanoistodus costatus, were previously reported from low-latitude conodont faunas from Australia, New Zealand and North China (Zhen et al. 2009). Identification of this species in relatively coolwater mid-latitude margins of Gondwana looks too interpretative in current state of knowledge

Figure 9. Atansoria yaseri sp. nov., sample MG10002/1. • A - NMW 2011.10G.117, ventral view of conjoined valves. • B - NMW 2011.10G.118, ventral view of conjoined valves. $\bullet$ C, D, F, J-NMW 2011.10G.116, conjoined valves, honeycomb epithelial imprints on the surface of the inner layers of the 

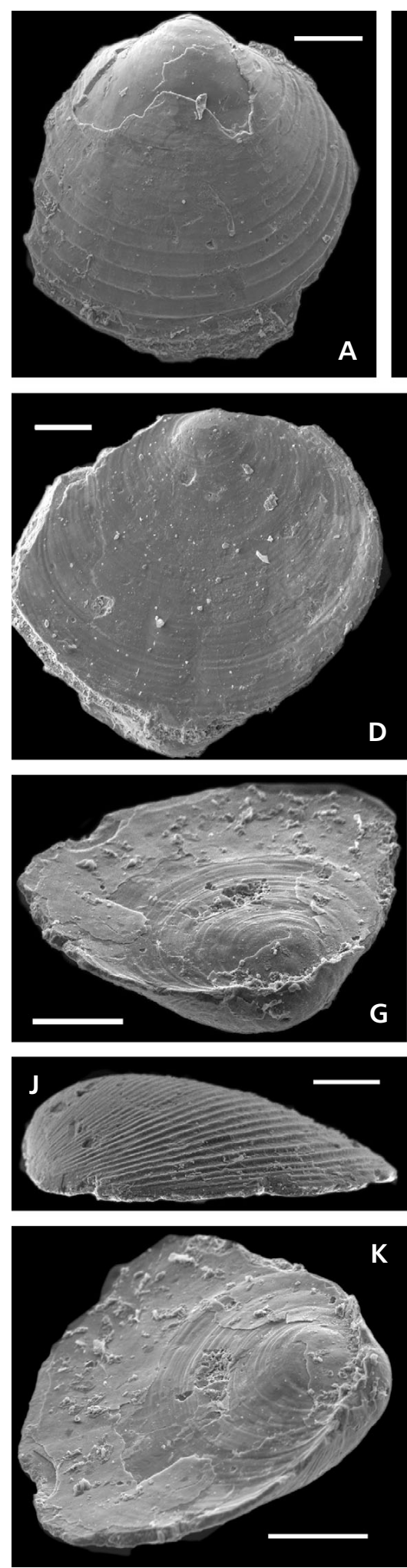
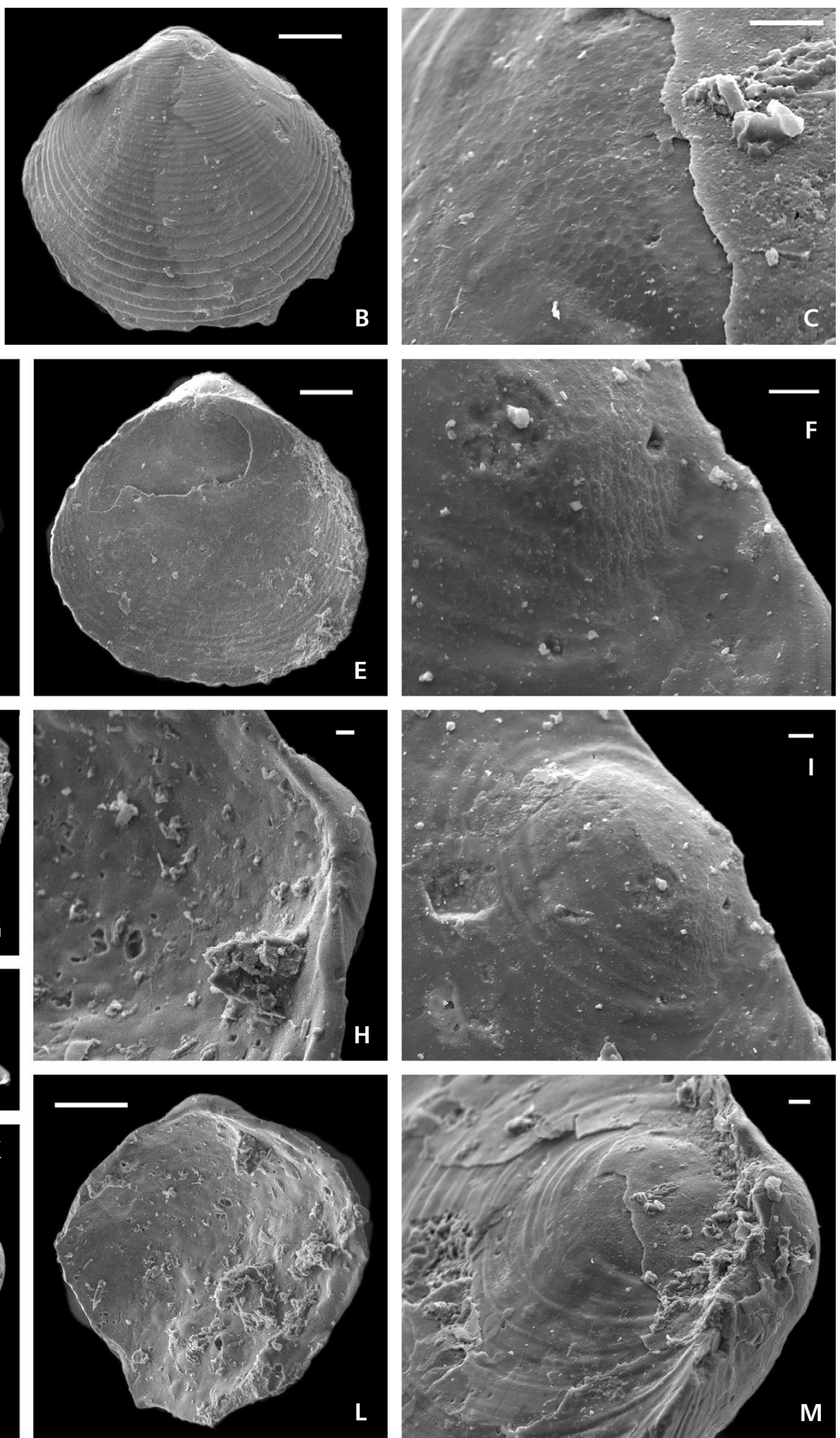

shell, dorsal view of exterior, dorsal umbonal region showing transition from larval to adult shell, dorsal umbo showing halo around larval shell. - E - NMW 2011.10G.128, holotype, dorsal view of conjoined valves. • G, K, M - NMW 2011.10G.119, conjoined valves, oblique posterior view, oblique lateral dorsal view, oblique view of conjoined valves showing dorsal umbo with larval shell. $\bullet$ H, L - NMW 2011.10G.121, ventral valve interior lacking ventral pseudointerarea oblique lateral view of interior. • J - NMW 2011.10G.120, lateral view of conjoined valves. C, F, H, I, M - scale bars are $10 \mu \mathrm{m}$; all other figures - scale bars are $100 \mu \mathrm{m}$. 
without a revision of the type material. In addition, the $M$ elements, assigned to Drepanoistodus sp., have smooth lateral sides in contrast to the costate $M$ elements of Drepanoistodus costatus from New Zealand (Zhen et al. 2009).

\section{Gen. et sp. indet. 1}

Figure $10 \mathrm{~N}-\mathrm{S}$

Material. - About 600 isolated elements, sample MG10002/1. Lower Ordovician, Floian, Seyahou Formation, Lower Member.

Remarks. - Composition of the inferred apparatus of this unnamed conodont taxon, as well as general morphology of $S a$ and $P$ elements differ significantly from all known Ordovician conodont genera and species. The suite of $S$ elements includes all prioniodontid $S$ element morphological types: $S a, S c, S b$ and $S d$. The $S c$ (Fig. 13O), $S b$ and $S d$ (Fig. 10N) elements are very similar to those of Baltoniodus or Trapezognathus in general morphology, but differ in having shorter and more discrete denticles on all processes. The $\mathrm{Sa}$ symmetrical element (Fig. 10R, S) is pentacostate with a broad anterior face, two costae on each side, posterior costa along the posterior margin, and cusp star-shaped in cross section. Typical prioniodontid $P$ and $M$ elements that theoretically could fit to observed $S$ elements are absent in the collection. The only elements in the assemblage besides those composing Baltoniodus aff. B. triangularis and Drepanoistodus sp. species are makellate (Fig. 10P, Q) that have long and wide reclined cusp and anterior and posterior processes of almost identical length with small regular denticles. The character of denticulation and shape of denticles resemble those of $S$ elements including pentacostate ones allowing to propose that all these elements may belong to one conodont species. The abundance of makellate elements is rather high indicating that they can be ana$\log$ s to $P$ or/and $M$ elements in prioniodontid plan of apparatuses.

Assignment of this taxon to any known genus is problematic. Pentacostate $S a$ elements occur in couple of Acodus species only (Zhen et al. 2003) and completely unknown in ramiform taxa. Combination of classical suite of $S$ elements with $P$ elements of makellate morphology is also not characteristic for any of known apparatuses.

\section{Chitinozoans (M. Ghavidel-Syooki)}

Allmost all discussed taxa are assigned to well known species, thus their formal systematic treatment is not given and a short summary is added. The classification system of $\mathrm{Pa}-$ ris et al. (1999) is used. The following symbols are adopted for systematic and biometric descriptions: $\mathrm{L}=$ total length of vesicle; 1 = length of chamber; ln = length of neck with collarette; $\mathrm{D}=$ maximum diameter of vesicle; dcoll = diameter of collarette; ls = length of spines; $\mathrm{L} / \mathrm{D}=$ total length of vesicle/maximum vesicle diameter; and $\mathrm{L} / \mathrm{ln}=$ total vesicle length/length of neck; $(\mathrm{x})=$ mean; $\mathrm{N}=$ number of specimens $;(\max )=$ maximum observed size $;(\min )=$ minimum observed size. When the chamber is less flattened than the neck, the chamber/neck diameter is restored according to the method proposed by Paris (1981) using a coefficient of 0.7 and 0.8 , respectively. Abundance values are expressed semi-quantitatively, as follows: rare $=2-3$ identified specimens; uncommon $=4-8$ identified specimens; common $=9-20$ identified specimens; abundant $>20$ identified specimens.

Order Prosomatifera Eisenack, 1931

Family Conochitinidae Eisenack, 1931 emend. Paris, 1981 Subfamily Conochitininae Eisenack, 1931 emend. Paris, 1981

\section{Genus Conochitina Eisenack, 1931 emend. Paris, Grahn, Nestor \& Lakova, 1999}

Type species. - Conochitina claviformis Eisenack, 1931 from Ordovician erratic boulders of Germany.

\section{Conochitina cf. poumoti Combaz \& Peniguel, 1972} Figure 11E

Material. - Two specimens from sample MG10002, and one specimen from sample MG10003. Lower to Middle Ordovician, Seyahou Formation, Desmochitina cf. ornensis Zone (upper Floian) and Siphonochitina formosa Zone (Darriwilian).

Dimensions. $-\mathrm{L}=246 \mu \mathrm{m}, \mathrm{Dp}=107 \mu \mathrm{m}$, dcoll $=72 \mu \mathrm{m}$, $\ln =113 \mu \mathrm{m}, \mathrm{L} / \mathrm{Dp}=2.3$.

Remarks. - Observed specimens are closely related to Conochitina poumoti because they have a convex base without a mucron and a short oral tube widening toward the aperture. The species has a restricted palaeogeographical distribution confined mainly to the North African segment of Gondwana, where it ranges from Floian to Darriwilian (Benoît \& Taugourdeau 1961, Taugourdeau et al. 1967).

Genus Euconochitina Taugourdeau, 1966 emend. Paris, Grahn, Nestor, Lakova, 1999

Type species. - Conochitina conulus Eisenack, 1955 from Ordovician erratic limestone boulders of Germany. 


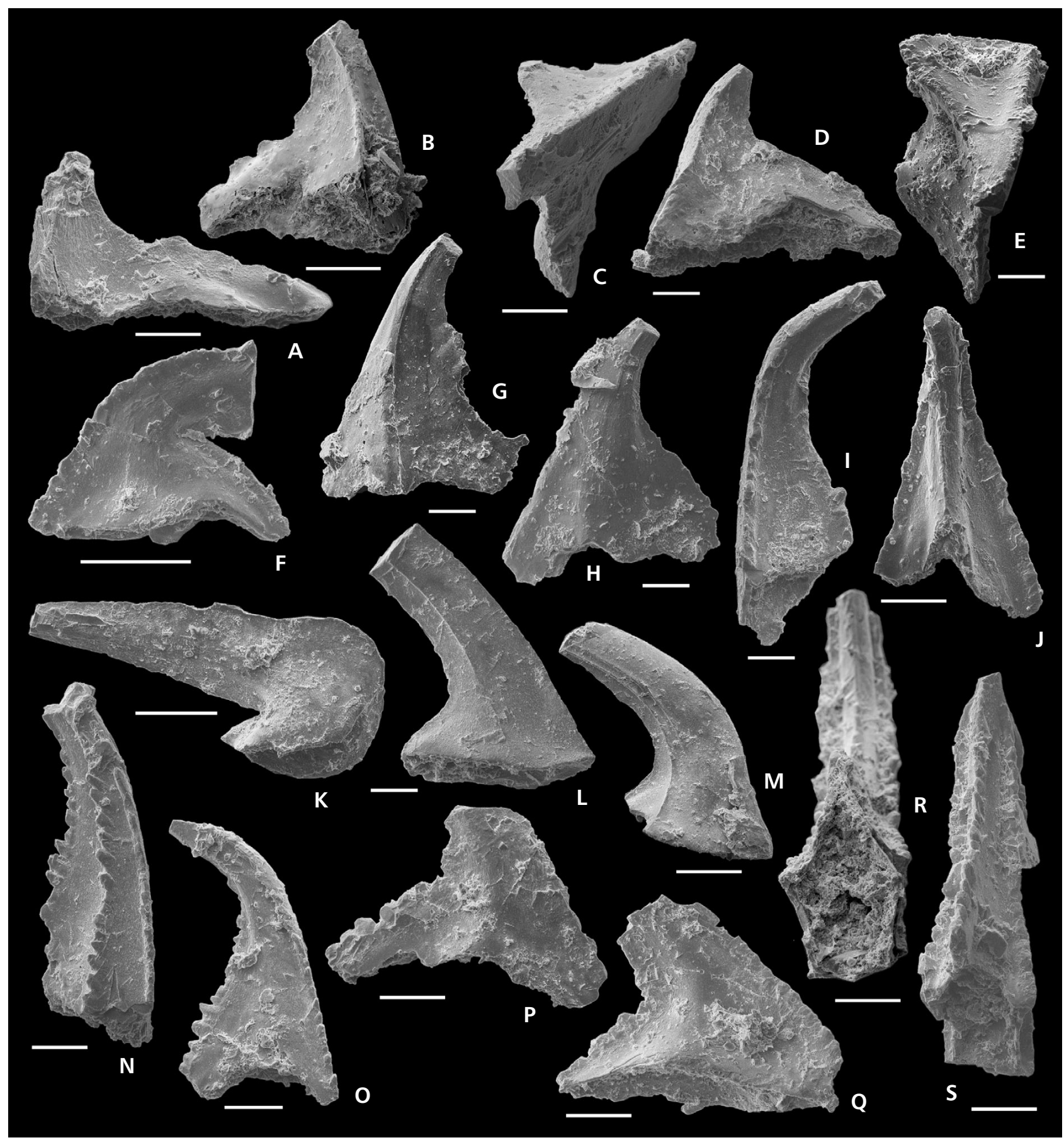

Figure 10. Late Floian conodonts from the lowermost Seyahou Formation in Faraghan Mountains, sample MG10002/1. • A-J - Baltoniodus aff. B. triangularis Lindström, 1955; A - CNIGR 1/13240, Pb element, lateral view; B - CNIGR 2/13240, Pa element, lateral view; C - CNIGR 3/13240, $P a$ element, upper view; D - CNIGR 4/13240, $P b$ element, lateral view; E - CNIGR 5/13240, $P b$ element, upper view; F - CNIGR 6/13240, $M$ element, lateral view; G - CNIGR 7/13240, Sb element, outer-lateral view; H - CNIGR 8/13240, Sc element, outer-lateral view; I - CNIGR 9/13240, Sd element, inner-lateral view; J - CNIGR 10/13240, Sa element, posterior view. $・$ K-M - Drepanoistodus sp.; K - CNIGR 10/13240, $M$ element; L - CNIGR 11/13240, $S$ element; M - CNIGR 12/13240, $S$ element. • N-S - gen. et sp. indet. 1; N - CNIGR 13/13240, Sd element, outer-lateral view; O - CNIGR 14/13240, Sc element, inner-lateral view; P - CNIGR 15/13240, P ? element, outer-lateral view; Q - CNIGR 16/13240, $P$ ? element, inner-lateral view; R - CNIGR 17/13240, Sa element, basal view; S - CNIGR 18/13240, Sa element, postero-basal view. All scale bars are $50 \mu \mathrm{m}$. 


\section{Euconochitina sp.}

Figure $11 \mathrm{H}$

Material. - Total 52 specimens from samples MG100011 to MG10013, MG10016-MG10018 (see absolute specimen abundance in Table 1). Upper Ordovician, Seyahou Formation, Middle Member, Acanthochitina barbata Zone (middle Katian).

Dimensions. $-\mathrm{L}=135 \mu \mathrm{m}, \mathrm{DP}=91.5 \mu \mathrm{m}$, dcoll $=57.5 \mu \mathrm{m}$, $\mathrm{L} / \mathrm{DP}=1.5$.

Remarks. - The specimens have an almost cylindrical vesicle with maximum diameter at $1 / 5$ to $1 / 3$ of maximum length from the base with a smooth wall and a straight aperture. Base of the vesicle is variable from flat to gently convex. All specimens are fairly poorly preserved; therefore their precise taxonomic assignation is ambiguous.

\section{Genus Rhabdochitina Eisenack, 1931}

Type species. - Rhabdochitina magna Eisenack, 1931 from erratic Ordovician limestone boulders of Germany.

\section{Rhabdochitina usitata Jenkins, 1967}

Figure 11S

Material. - Total 25 specimens from samples MG100011-MG10018 (see absolute specimen abundance in Table 1). Upper Ordovician, Seyahou Formation, Middle Member, Acanthochitina barbata Zone (middle Katian).

Dimensions. $-\mathrm{L}(\max )=250 \mu \mathrm{m}, \mathrm{L}(\mathrm{x})=182 \mu \mathrm{m}, \mathrm{L}(\min )=$ $113.5 \mu \mathrm{m}, \mathrm{DP}(\max )=80 \mu \mathrm{m}, \mathrm{DP}(\mathrm{x})=59.25 \mu \mathrm{m}, \mathrm{DP}(\min )$ $=38.5 \mu \mathrm{m}, \operatorname{dcoll}(\max )=60 \mu \mathrm{m}, \operatorname{dcoll}(\mathrm{x})=55 \mu \mathrm{m}$, $\operatorname{dcoll}(\min )=50 \mu \mathrm{m}$.

Remarks. - Specimens from the Seyahou Formation are characterised by a cylindrical vesicle shape with maximum diameter located at 1/5 to $1 / 3$ maximum length from the base, smooth wall, a hemispherical base with a basal scare and a straight aperture typical for the species; however, they have somewhat smaller sizes than British specimens described by Jenkins (1967) and the specimens described and illustrated by Jenkins (1969) from the Ordovician of the Viola and Fernvale formations of the Arbruckle Mountains in Oklahoma.

Subfamily Belinichitininae Paris, 1981

\section{Genus Acanthochitina Eisenack, 1931}

Type species. - Acanthochitina barbata Eisenack, 1931 from the Katian (regional Vormsi Stage) of Baltoscandia.
Acanthochitina barbata Eisenack, 1931

Figure 11Q, U

Material. - Total 22 specimens from samples MG100011-MG100017 (see absolute specimen abundance in Table 1). Upper Ordovician, Seyahou Formation, Middle Member, Acanthochitina barbata Zone (middle Katian).

Dimensions. $-\mathrm{L}(\max )=459 \mu \mathrm{m}, \mathrm{L}(\mathrm{x})=352 \mu \mathrm{m}, \mathrm{L}(\min )=$ $245 \mu \mathrm{m}, \mathrm{Dp}(\max )=150 \mu \mathrm{m}, \mathrm{Dp}(\mathrm{x})=19, \mathrm{Dp}(\min )=88 \mu \mathrm{m}$, $\mathrm{dcoll}(\max )=100.5, \operatorname{dcoll}(\mathrm{x})=85, \operatorname{dcoll}(\min )=68 \mu \mathrm{m}$, $\operatorname{ls}(\max )=17 \mu \mathrm{m}, \operatorname{ls}(\mathrm{x}) 11, \operatorname{ls}(\min )=6 \mu \mathrm{m}, \mathrm{L} / \mathrm{Dp}(\max )=3$, $\mathrm{L} / \mathrm{Dp}(\mathrm{x})=2.95, \mathrm{~L} / \mathrm{Dp}(\min )=2.8, \mathrm{~N}=10$.

Remarks. - In Iran this species was previously reported by Ghavidel-Syooki \& Winchester-Seeto (2002) from the Middle-Upper Ordovician Ghelli Formation of the Northern Khorosan Province; specimens from the Seyahou Formation are closely similar, but somewhat larger in size.

Subfamily Belonechitininae Paris, 1981

\section{Genus Belonechitina Jansonius, 1964}

Type species. - Conochitina micracantha robusta Eisenack, 1959 from the Katian Saku Member (Wasalemma Formation) of North Estonia.

\section{Belonechitina robusta (Eisenack, 1959)} Figure 11O, P

Material. - Total specimens from samples MG10011-MG10018 (see absolute specimen abundance in Table 1). Upper Ordovician, Seyahou Formation, Middle Member, Acanthochitina barbata Zone (middle Katian).

Dimensions. $-\mathrm{L}=247 \mu \mathrm{m}, \mathrm{Dp}=91 \mu \mathrm{m}$, dcoll $=73 \mu \mathrm{m}$, $\mathrm{L} / \mathrm{Dp}=2.7, \mathrm{~N}=5$.

Remarks. - Specimens from Zagros show multiroot spines on a surface of the vesicle, which are characteristic of Belonechitina robusta. In the Arabian Peninsula this species occurs in the Haima Supergroup of Oman (Molyneux et al. 2006), whereas in Iran it was recently reported from the Gorgan Schists in the northern Alborz Mountains (Ghavidel-Syooki 2008).

Belonechitina micracantha Eisenack, 1931 Figure 11T, V

Material. - Total 26 specimens from samples MG10011, MG10012 and MG10014-MG10017 (see absolute speci- 

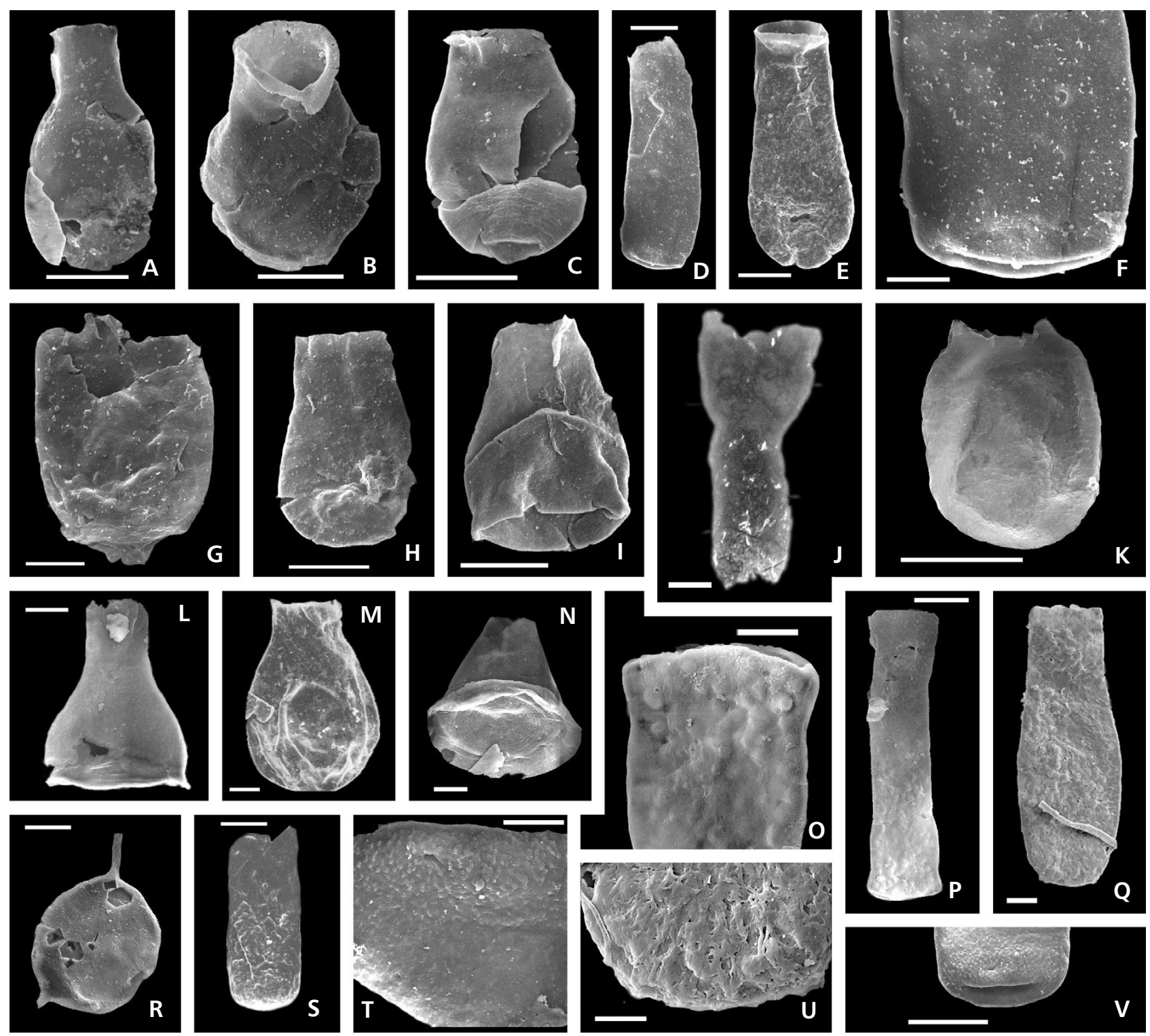

Figure 11. A, B - Lagenochitina $\mathrm{cf}$. obeligis Paris, 1981, NIOC/MG10002/IOOC/SEM/ stub 1, sample MG10002. • C - Desmochitina cf. ornensis Paris, 1981, NIOC/MG10002/IOOC/SEM/ stub 1, sample MG10002. • D - Conochitina sp., NIOC/MG10002/IOOC/SEM/ stub 1, sample MG10002. - E - Conochitina cf. poumoti Combaz \& Péniguel, 1972, NIOC/MG10002/IOOC/SEM/ stub 1, sample MG10002. • F - Conochitina sp., NIOC/MG10002/IOOC/SEM/ stub 1, sample MG10002. • G - Eremochitina sp., NIOC/MG10002/IOOC/SEM/ stub 1, sample MG10002. - H - Euconochitina sp. NIOC/MG10002/IOOC/SEM/stub 1, sample MG10002. - I - Cyathochitina dispar Benoit \& Taugourdeau, 1961, NIOC/MG10002/IOOC/SEM/ stub 1, sample MG10002. • J - Siphonochitina formosa Jenkins, 1967, NIOC/MG10003/IOOC/SEM/ stub 1, sample MG10003. $\bullet \mathrm{K}$ - Desmochitina minor Eisenack, 1931, NIOC/MG10011/IOOC/SEM/ stub 1, sample MG10011. $\bullet$ L - Cyathochitina campanulaeformis (Eisenack, 1931), NIOC/MG10011/IOOC/SEM/stub 1, sample MG10011. • M - Lagenochitina baltica Eisenack, 1931, NIOC/MG10011/IOOC/SEM/ stub 1, sample MG10011. - N - Cyathochitina latipatagium Jenkins, 1969, NIOC/MG10013/IOOC/SEM/ stub 1, sample MG10013. • O, P - Belonechitina robusta (Eisenack, 1959), NIOC/MG10011/IOOC/SEM/ stub 1, sample MG10011. • Q, U - Acanthochitina barbata Eisenack, 1931 emend. Jenkins, 1967, NIOC/MG10011/IOOC/SEM/ stub 2, sample MG10011. - R - Orthosphaeridium bispinosum Turner, 1984, NIOC/MG10012/IOOC/SEM/ stub 2, sample MG10012. • S - Rhabdochitina usitata Jenkins, 1967, NIOC/MG10011/IOOC/SEM/ stub 1, sample MG10011. • T, V - Belonechitina micracantha Eisenack, 1931, NIOC/MG10011/IOOC/SEM/ stub 1, sample MG10011. E, H-L, N, P, Q, S, V - scale bars are $50 \mu \mathrm{m}, \mathrm{F}, \mathrm{G}, \mathrm{M}, \mathrm{O}, \mathrm{R}, \mathrm{T}, \mathrm{U}$ - scale bars are $20 \mu \mathrm{m}, \mathrm{J}$ - scale bars are $10 \mu \mathrm{m}$. 
men abundance in Table 1). Upper Ordovician, Seyahou Formation, Middle Member, Acanthochitina barbata Zone (middle Katian).

Dimensions. $-\mathrm{L}=323 \mu \mathrm{m}, \mathrm{DP}=85 \mu \mathrm{m}, \mathrm{d}$ coll. $=69 \mu \mathrm{m}$, $\mathrm{sl}=8.5 \mu \mathrm{m}, \mathrm{L} / \mathrm{Dp}=3.8, \mathrm{~N}=20$.

Description. - Long, cylindrical vesicle lacking distinct flexure; flanks tapering slightly towards the aperture. Base varying from strongly concave to almost flat, with rounded basal edges. Vesicle surface with spines densely covering a basal margin of the chamber.

Remarks. - Despite the slight distortion suffered by the specimens, and their common pyritisation, they exhibit all the diagnostic features of the taxon. Although the species co-occurs with Belonechitina robusta, the former can be distinguished in having simple, conical (not bifurcating) spines covering the entire test surface, including the basal margin. Due to its long stratigraphical range, biostratigraphical application of Belonechitina micracantha is relatively limited.

\section{Subfamily Eremochitininae Paris, 1981}

\section{Genus Siphonochitina Jenkins, 1967}

Type species. - Siphonochitina formosa Jenkins, 1967 from the Darriwilian (Middle Ordovician) upper Hope Shale of Shropshire, UK.

\section{Siphonochitina formosa Jenkins, 1967}

Figure 11J

Material. - Total eight specimens from samples MG10003, MG10006 and MG10008 (see absolute specimen abundance in Table 1). Middle Ordovician, Seyahou Formation, Middle Member, Siphonochitina formosa Zone (Darriwilian).

Remarks. - Although the neck in all specimens has been broken; however they exhibit a siphon, firmly attached to the centre of the base, and show a conical chamber with slightly convex base, leaving no doubts about their taxonomic attribution to Siphonochitina formosa. In particular, they show close morphological similarity to the types described and illustrated by Jenkins (1967).

Family Lagenochitinidae Eisenack, 1931 emend. Paris, 1981 Subfamily Lagenochitininae Eisenack, 1931 emend. Paris, 1981

\section{Genus Lagenochitina Eisenack, 1931 emend. Paris, Grahn, Nestor \& Lakova, 1999}

Type species. - Lagenochitina baltica Eisenack, 1931 from Ordovician erratic boulders of the Baltic shore in Germany.

\section{Lagenochitina baltica Eisenack, 1931 Figure 11M}

Material. - Total 20 specimens from samples MG10011, Mg10012, MG10014-MG10017 and MG10019 (see absolute specimen abundance in Table 1). Upper Ordovician, Seyahou Formation, Middle Member, Acanthochitina barbata Zone (middle Katian).

Dimensions. $-\mathrm{L}=139 \mu \mathrm{m}, \mathrm{DP}=91 \mu \mathrm{m}$, dcoll $=46 \mu \mathrm{m}$, $\ln =28 \mu \mathrm{m}, \mathrm{N}=10$.

Description. - Ovoid vesicle with a short cylindrical neck, distinct flexure and flanks tapering slightly towards the aperture. Vesicle surface smooth or finely granulose.

Remarks. - The specimens of Lagenochitina baltica from the Seyahou Formation have a smaller vesicle than representatives of this taxon known from Baltica (Grahn 1982) and Avalonia (Jenkins 1967), but otherwise have no significant morphological differences and therefore considered here conspecific.

\section{Lagenochitina cf. obeligis Paris, 1981}

Figure 11A, B

Material. - Total 13 specimens from samples MG10002-MG10007 (see absolute specimen abundance in Table 1). Lower to Middle Ordovician, Seyahou Formation, Desmochitina cf. ornensis Zone (upper Floian) and Siphonochitina formosa Zone (Darriwilian).

Dimensions. $-\mathrm{L}=149 \mu \mathrm{m}, \mathrm{DP}=71 \mu \mathrm{m}$, dcoll $=41 \mu \mathrm{m}$, $\ln =45 \mu \mathrm{m}, \mathrm{L} / \mathrm{Dp}=2, \mathrm{~N}=3$.

Remarks. - Lagenochitina obeligis is a long-ranging taxon, which appears in the upper part of the Eremochitina brevis Zone and ranges up to the Darriwilian (e.g. Paris 1981, table 1; Samuelsson \& Verniers 2000, figs 4, 5). It is used as the index species of the Lagenochitina obeligis Zone in the Lower-Middle Ordovician sequence of the South American segment of Gondwana (Grahn 2006). In the test morphology Iranian specimens show close similarity to the types described and illustrated by Paris (1981) except being somewhat smaller. 
Subfamily Cyatochitininae Paris, 1981

Genus Cyathochitina Eisenack, 1955 emend. Paris, Grahn, Nestor \& Lakova, 1999

Type species. - Conochitina companulaeformis Eisenack, 1931 from the Darriwilian (regional Uhaku Stage) of Baltoscandia.

Cyathochitina campanulaeformis (Eisenack, 1931) Figure 11L

Material. - Total 33 specimens from sample MG10013, MG10014, MG10015-MG10019 (see absolute specimen abundance in Table 1). Upper Ordovician, Seyahou Formation, Middle Member, Acanthochitina barbata Zone (middle Katian).

Dimensions. $-\mathrm{L}=217 \mu \mathrm{m}, \mathrm{DP}=149.5 \mu \mathrm{m}, \mathrm{ln}=92 \mu \mathrm{m}$, dcoll $=71 \mu \mathrm{m}$, width of carina $=17 \mu \mathrm{m}, \mathrm{L} / \mathrm{Dp}=1.5, \mathrm{~N}=15$.

Remarks. - In Iran this species was previously documented from the Ghelli Formation of North Khorosan Province (Ghavidel-Syooki \& Winchester-Seeto 2002) and the Gorgan Schists of northern Eastern Alborz (Ghavidel-Syooki 2008); both occurrences were confined to the Upper Ordovician.

\section{Cyathochitina latipatagium Jenkins, 1969}

Figure 11N

Material. - Total 31 specimens from samples MG10013-MG10019 (see absolute specimen abundance in Table 1). Upper Ordovician, Seyahou Formation, Middle Member, Acanthochitina barbata Zone (middle Katian).

Dimensions. $-\mathrm{L}=195 \mu \mathrm{m}, \mathrm{DP}=173$, width of carina $=$ $48 \mu \mathrm{m}, \mathrm{L} / \mathrm{Dp}=1.3$. Four specimens were measured.

Remarks. - The specimens from the Seyahou Formation are characterised by a smooth, conical vesicle with a convex base. Maximum diameter of the chamber is situated near the basal edges and its carina is fairly wider $(48 \mu \mathrm{m})$ than in Cyathochitina kuckersiana kuckersiana Jenkins (1969). The neck is short, slightly flares towards the aperture and concentric rings are present in the basal margin.

\section{Cyathochitina dispar Benoît \& Taugourdeau, 1961 Figure 11I}

Material. - Two specimens from sample MG10002 and one specimen from sample MG10003. Lower to Middle
Ordovician, Seyahou Formation, Desmochitina cf. ornensis Zone (upper Floian) and Siphonochitina formosa Zone (Darriwilian).

Dimensions. $-\mathrm{L}=130 \mu \mathrm{m}, \mathrm{Dp}=91 \mu \mathrm{m}$, dcoll $=47 \mu \mathrm{m}$, $\mathrm{L} / \mathrm{Dp}=1.4$.

Remarks. - This species has been discussed recently in more details by de la Puente (2010); however, the specimen of Cyathochitina sp. cf. C. dispar Benoît \& Taugourdeau, 1961, described and illustrated in this publication, is incomplete and twice as large as the Iranian specimens, while its species attribution looks doubtful. Due to wide range biostratigraphical application of this species is rather limited.

Order Operculatifera Eisenack, 1931

Family Desmochitinidae Eisenack, 1931 emend. Paris, 1981

Subamily Desmochitininae Eisenack, 1931 emend. Paris, 1981

\section{Genus Desmochitina Eisenack, 1931}

Type species. - Desmochitina nodosa Eisenack, 1931 from the Upper Ordovician (Keila Regional Stage) of Baltoscandia.

\section{Desmochitina cf. ornensis Paris, 1981 \\ Figure 11C}

Material. - Two specimens from sample MG10002. Lower Ordovician, Seyahou Formation, Lower Member, Desmochitina cf. ornensis Zone (upper Floian).

Dimensions. $-\mathrm{L}=111 \mu \mathrm{m}, \mathrm{DP}=81 \mu \mathrm{m}$, dcoll $=44 \mu \mathrm{m}$, $\mathrm{L} / \mathrm{Dp}=1.4$.

Remarks. - This taxon is present only in sample MG10002. Desmochitina ornensis is considered as the index species of the lowermost Dapingian chitinozoan biozone in the "North Gondwana Domain"; however, in Zagros it appears just below the occurrence of latest Floian conodonts.

\section{Desmochitina minor Eisenack, 1931 Figure 11K}

Material. - Total 17 specimens from samples MG10011, MG10012 and MG10015-MG10018 (see absolute specimen abundance in Table 1). Upper Ordovician, Seyahou Formation, Middle Member, Acanthochitina barbata Zone (middle Katian). 
Dimensions. $-\mathrm{L}=102 \mu \mathrm{m}$ including collar, dcoll $=43 \mu \mathrm{m}$, lc $=9 \mu \mathrm{m}, \mathrm{N}=10$.

Remarks. - Desmochitina minor is a cosmopolitan taxon with a very long stratigraphical range, which is in need of substantial revision. As it was commented by Grahn (1984), it is probably a "waste basket" binomen, which is used for a number of morphologically similar species.

\section{Conclusions}

In the Faraghan Mountains of the Zagros Ranges, the Zard-Kuh/Seyahou transition has been studied in an attempt to determine the range of the stratigraphic gap involved at the top of a phosphoritic bed that covers the lower black shale-dominated member of the Seyahou Formation. Based on comparisons with successions of the neighbouring Arabian Peninsula, the reported chitinozoans and conodonts suggest the onset of a hiatus representative of the Dapingian-early Darriwilian interval and ranging to at least five chitinozoan biozones. Similar gaps marking the Lower-Middle Ordovician transition are recognized at the Saq/Qasim (central part of Arabian Peninsula), Ghudum/Saih Nihayda (Oman), and Rann/Ayim (UAE) lithostratigraphic contacts. Mid Ordovician phosphogenesis associated with starvation, reworking and redeposition, and the onset of distinct stratigraphic gaps was a complex process recorded throughout the Arabian margin of Gondwana. Maximum flooding and phosphate precipitation is suggested as the counterpart in the Zagros Ranges of the Helskjer Drowning Event of Baltoscandia and the third-order maximum flooding surface that punctuates the Siphonochitina formosa Zone in North Africa.

\section{Acknowledgements}

Research of Mohammad Ghavidel-Syooki has been financed by the Iranian Offshore Oil Company (IOOC). Mansoureh Ghobadi Pour and Leonid Popov acknowledge logistical support from the National Museum of Wales. Fieldwork and research in Iran of Mansoureh Ghobadi Pour were supported by the Golestan university. Reza Zare and Yaser Sheikhan are thanked for field assistance. We are grateful to Rainer Brocke and Florentin Paris for helpful and constructive critical reviews of the manuscript. Christian Baars (National Museum of Wales) kindly assisted us with SEM photography.

\section{References}

Aвaimova, G.P. 1971. New Early Ordovician conodonts of the south-eastern Siberian Platform. Paleontologicheskii Zhurnal 1971(4), 74-81. [in Russian]
Аснав, A. 1982. Chitinozoaires de l'Arenig supérieur (Zone D) de la Formation de Uvis, Québec, Canada. Canadian Journal of Earth Sciences 19, 1295-307. DOI 10.1139/e82-110

Аснав, A. 1986. Assemblages de chitinozoaires dans 1'Ordovicien Inférieur de 1'Est du Canada. Canadian Journal of Earth Sciences 23, 269-94. DOI 10.1139/e86-068

Afaghi, A. \& SaleK, M.M. (eds) 1977. Geological Map of Iran, South-Central Iran, sheet no. $5(1 / 1,000,000)$. National Iranian Oil Company, Exploration and Production.

Ainsaar, L., Kaljo, D., Martma, T., Meidla, T., Männik, P, NõlvaK, J. \& Tinn, O. 2010. Middle and Upper Ordovician carbon isotope chemostratigraphy in Baltoscandia: A correlation standard and clues to environmental history. Palaeogeography, Palaeoclimatology, Palaeoecology 294, 189-201. DOI 10.1016/j.palaeo.2010.01.003

AlBANI, R. 1989. Ordovician (Arenigian) acritarchs from the Solanas Sandstone Formation, central Sardinia, Italy. Bollettino della Società Paleontologica Italiana 28, 3-37.

Albani, R., Bagnoli, G., Maletz, J. \& Stouge, S. 2001. Intergrated chitinozoan, conodont, and graptolite biostratigraphy from the upper part of the Cape Cormorant Formation (Middle Ordovician), western Newfoundland. Canadian Journal of Earth Sciences 38, 387-409. DOI 10.1139/e00-081

AL-HAJRI, S. 1995. Biostratigraphy of the Ordovician Chitinozoa of northwestern Saudi Arabia. Review of Palaeobotany and Palynology 89, 27-48. DOI 10.1016/0034-6667(95)00040-5

Armstrong, H.A., Turner, B.R., Makhlouf, I.M., Weedon, G.P., Williams, M., Al Smadi, A. \& Abu Salah, A. 2005. Origin, sequence stratigraphy and depositional environment of an upper Ordovician (Hirnantian) deglacial black shale, Jordan. Palaeogeography, Palaeoclimatology, Palaeoecology 220, 273-289. DOI 10.1016/j.palaeo.2005.01.007

BAgnoli, G. \& Stouge, S. 1997. Lower Ordovician (Billingenian-Kunda) conodont zonation and provinces based on sections from Horns Udde, north Öland, Sweden. Bollettino della Società Paleontologica Italiana 35, 109-63.

Benoît, A. \& Taugourdeau, P. 1961. Sur quelques Chitinozoaires de l'Ordovicien du Sahara. Revue de l'Institut Français du Pétrole 16, 1403-21.

Bergeron, J. 1893. Notes Paléontologiques. 1. Crustacés. Bulletin de la Société géologique de France 21, 333-346.

Bergström, S.M. 1962. Conodonts from the Ludibundus Limestone (Middle Ordovician) of the Tvaren area (S. E. Sweden). Arkiv för Mineralogi och Geologi 3, 1-61.

Bergström, S.M. \& LöfGren, A. 2009. The base of the global Dapingian Stage (Ordovician) in Baltoscandia: conodonts, graptolites and unconformities. Transactions of the Royal Society of Edinburgh, Earth and Environmental Science 99, $189-212$.

Bockelie, T.G. 1980. Early Ordovician Chitinozoa from Spitsbergen. Palynology 4, 1-14. DOI 10.1080/01916122.1980.9989198

BouchÉ, P.M. 1965. Chitinozoaires du Silurien s.1 du Djado (Sahara nigérien). Revue de Micropaléontologie 8, 151-64.

Brocke, R. 1998. Palynomorphs (Acritarchen, Prasinophyceae, Chlorophyceae) aus dem Ordovizium der Yangtze-Platform, Südwest China. 225 pp. Unpublished Ph.D. thesis, Technische Univesität Berlin. 
Brocke, R., Fatka, O. \& Servais, T. 1998. A review of the Ordovician acritarchs Aureotesta and Marrocanium. Annales de la Société Géologique de Belgique 120, 1-21.

Burmann, G. 1968. Diacrodien aus dem unteren Ordovizium. Paläontologische Abhandlungen, Abteilung B, Paläobotanik 2, 653-793.

Burmann, G. 1970. Weitere organische Mikrofossilien aus dem unteren Ordovizium. Paläontologische Abhandlungen, Abteilung B, Paläobotanik 3, 289-332.

Chen, X., Paris, F., Wang, X. \& Zhang, M. 2009. Early and Middle Ordovician chitinozoans from the Dapingian type sections, Yichang area, China. Review of Palaeobotany and Palynology 153, 310-330. DOI 10.1016/j.revpalbo.2008.09.006

Clark-Lowes, D.D. 2005. Arabian glacial deposits: recognition of palaeovalleys within the Upper Ordovician Sarah Formation, Al Qasim district, Saudi Arabia. Proceedings of the Geological Association 116, 331-347.

DOI 10.1016/S0016-7878(05)80051-3

Combaz, A. \& Peniguel, G. 1972. Étude palynostratigraphique de l'Ordovicien dans quelques sondages du Bassin de Canning (Australie Occidentale). Bulletin du Centre de Recherches de Pau S.N.P.A. 6, 121-167.

Cramer, F.H., Allam, B., Kanes, W.H. \& Díez, M.d.C.R. 1974. Upper Arenigian to Lower Llanvirnian from the subsurface of Tadla Basin in Morocco. Palaeontographica, Abteilung B 145, 182-190.

CRAmer, F.H. \& DíEz, M.D.C.R. 1976. Seven new late Arenigian species of the acritarch genus Coryphidium Vavrdová, 1972. Paläontologische Zeitschrift 50, 201-208. DOI 10.1007/BF02987693

Cramer, F.H. \& Díez, M.D.C.R. 1977. Late Arenigian (Ordovician) acritarchs from Cis-Saharan, Morocco. Micropaleontology 23, 339-360. DOI 10.2307/1485220

Dabard, M.P., Loi, A. \& Paris, F. 2007. Relationship between phosphogenesis and sequence architecture: sequence stratigraphy and biostratigraphy in the Middle Ordovician of the Armorican Massif (NW France). Palaeogeography, Palaeoclimatology, Palaeoecology 248, 339-356.

DOI 10.1016/j.palaeo.2006.12.011

DEAn, W.T. 1967. The correlation and trilobite fauna of the Bedinan Formation in South Eastern Turkey. Bulletin of the British Museum (Natural History), Geology 15, 83-123.

DeunFF, J. 1955. Aremoricanium, genre nouveau d'Hystrichosphères du Silurien Breton. Comptes Rendus de la Société géologique de France (nouvelle série) 5, 227-229.

DeunFF, J. 1959. Microorganismes planctoniques du Primaire Armoricain. I. Ordovicien du Veryhac'h (Presqu'île deu Crozon). Bulletin de la Société géologique et minéralogique de Bretagne (nouvelle série) 2, 1-41.

DeunFF, J. 1961. Un microplancton à Hystrichosphéres dans le Trémadoc du Sahara. Revue de Micropaléontologie 4, 37-52.

DeunfF, J., Górka, H. \& Rauscher, R. 1974. Observations nouvelles et précisions sur les Acritarches a large ouverture polaire du Paléozoique Inférieur. Geobios 7, 5-18. DOI 10.1016/S0016-6995(74)80016-1

DownIE, C. 1959. Hystrichospheres from the Silurian Wenlock Shale of England. Palaeontology 2, 56-71.

DzIK, J. 1983. Relationships between Ordovician Baltic and
North American Midcontinent conodont faunas. Fossils and Strata 15, 59-86.

EISENACK, A. 1931. Neue Mikrofossilien des baltischen Silurs I. Palaeontologische Zeitschrift 13, 74-118.

DOI 10.1007/BF03043326

EISENACK, A. 1938. Hystrichosphäriden und verwandten Formen im baltischen Silur. Z. Geschiebeforschung 14, 1-30.

EIsEnACK, A. 1955. Chitinozoen, Hystrichosphaeren und andere Mikrofossilien aus dem Beyrichia Kalk. Senckenbergiana lethaea $36,157-188$.

EISENACK, A. 1959. Neotypen baltischer Silur-Hystrichosphären und neue Arten. Palaeontographica, Abteilung A 112, 193-211.

EISENACK, A. 1962. Neotypen baltischer Silur-Chitinozoen und neue Arten. Neues Jahrbuch für Geologie und Paläontologie, Abhandlungen 114, 291-316.

EisenACK, A. 1963. Mitteilungen zur Biologie der Hystrichosphären und neue Arten. Palaeontographica, Abteilung A 118, 207-216.

Elaouad-DebBaj, Z. 1984. Chitinozoaires ashgilliens de l'AntiAtlas (Maroc). Geobios 17, 45-68. DOI 10.1016/S0016-6995(84)80005-4

El-Khayal, A.A. \& Romano, M. 1988. A revision of the upper part of the Saq Formation and Hanadir Shale (Lower Ordovician) of Saudi Arabia. Geological Magazine 125, 161-174. DOI $10.1017 /$ S0016756800009560

Elles, G.L. \& Wood, E.M.R. 1901. A monograph of British graptolites. Part 1 Dichograptidae. Monographs of the Palaeontographical Society 55, 1-54.

FAtKA, O. \& BRocke, R. 1999. Morphologic variability in two populations of Arbusculidium filamentosum (Vavrdová 1965). Palynology 23, 153-180.

DOI 10.1080/01916122.1999.9989526

Fensome, R.A., Williams, G.L., Barss, M.S., Freeman, J.M. \& HiLl, J.M. 1990. Acritarchs and fossil prasynophytes: an index to genera, species and intraspecific taxa. A.A.S.P. Contribution Series 25, 1-171.

Fortey, R.A., Heward, A.P. \& Miller, C.G. 2011. Sedimentary facies and trilobite and conodont faunas of the Ordovician Rann Formation, Ras Al Khaimah, United Arab Emirates. GeoArabia 16, 127-152.

GHAvIDEL-SYooki, M. 1998. Investigation of Late Palaeozoic strata on Tang-e Zakeen and introduction of Zakeen Formation in Kuh-e Faraghan, Zagros Basin, southern Iran. Geosciences Scientific Quarterly Journal 7, 54-73.

GHAVIDEL-SYooki, M. 2000. Biostratigraphy and palaeobiogeography of Late Ordovician and Early Silurian chitinozoans from Zagros Basin, southern Iran. Historical Biology 15, 29-39. DOI 10.1080/10292380109380580

GHAVIDEL-SYooki, M. 2001. Palynostratigraphy and Palaeobiogeography of the Lower Palaeozoic sequence in the northeastern Alborz Range (Kopet-Dagh region) of Iran, 17-35. In Goodman, D.K. \& Clarke, R.T. (eds) Proceedings of the IX International Palynological Congress Houston, Texas, U.S.A., 1996. American Association of Stratigraphic Palynologists Foundation.

GHAVIDEL-SYooki, M. 2008. Palynostratigraphy and Palaeogeography of the Upper Ordovician Gorgan Schists (Southeast- 
ern Caspian Sea), Eastern Alborz Mountain ranges, Northern Iran. Comunicações Geológicas 95, 123-155.

Ghavidel-Syooki, M., Álvaro, J.J., Popov, L.E., Ghobadi Pour, M., Ehsani, M.H. \& Suyarkova, A. 2011. Stratigraphic evidence for the Hirnantian (latest Ordovician) glaciation in the Zagros Mountains, Iran. Palaeogeography, Palaeoclimatology, Palaeoecology 307, 1-16. DOI 10.1016/j.palaeo.2011.04.011

GHAVIDEL-SYOoKI, M. \& KHOSRAVI, M.E. 1995. Investigation of Lower Palaeozoic sediments at Tang-e Zakeen of Kuh-e Faraghan and introduction of Seyahou and Sarchahan formations in the Zagros Basin, southern Iran. Geosciences Scientific Quarterly Journal 4, 2-21.

Ghavidel-Syooki, M. \& Winchester-Seeto, T. 2002. Biostratigraphy and palaeogeography of Late Ordovician chitinozoans from the northeastern Alborz Range, Iran. Review of Palaeobotany and Palynology 118, 77-99.

DOI 10.1016/S0034-6667(01)00108-7

Ghobadi Pour, M. 2006. Early Ordovician (Tremadocian) trilobites from Simeh-Kuh, Eastern Alborz, Iran, 93-118. In Bassett, M.G. \& Deisler, V.K. (eds) Studies in Palaeozoic palaeontology. National Museum of Wales Geological Series 25.

Ghobadi Pour, M., Popov, L.E., Kebria-ee Zadeh, M.R. \& BAARs, C. 2011. Middle Ordovician (Darriwilian) brachiopods associated with the Neseuretus biofacies, eastern Alborz Mountains, Iran. Memoirs of the Association of Australasian Palaeontologists 42, 263-283.

Ghobadi Pour, M., Vidal, M. \& Hosseini-Nezhad, M. 2007. An Early Ordovician trilobite assemblage from the Lashkarak Formation, Damghan area, northern Iran. Geobios 40, 489-500. DOI 10.1016/j.geobios.2005.04.007

GoRJANSKY, V.Y. \& POPOV, L.E. 1985. Morphology, systematic position and the origin of inarticulated brachiopods with carbonate shell. Paleontologicheskii Zhurnal 1985(3), 3-14. [in Russian]

Grahn, Y. 1982. Caradocian and Ashgillian Chitinozoa from the subsurface of Gotland. Sveriges Geologiska Undersökning C788, 1-66.

Grahn, Y. 1984. Ordovician Chitinozoa from Tallinn, northern Estonia. Review of Palaeobotany and Palynology 43, 5-31. DOI 10.1016/0034-6667(84)90025-3

GRAHN, Y. 2006. Ordovician and Silurian chitinozoan biozones of western Gondwana. Geological Magazine 143, 509-529. DOI 10.1017/S001675680600207X

Gutiérrez-Marco, J.C., Sá, A.S., García-Bellido, D.C. \& RÁBAno, I. 2013. The extent of the Dapingian Stage (Middle Ordovician) in peri-Gondwanan Europe and North Africa: Stratigraphic record, biostratigraphic tools, and regional chronostratigraphy, 114-115. In Lindskog, A. \& MeHLQvist, K. (eds) Proceedings of the $3^{\text {rd }}$ IGCP 591 Annual Meeting, 9-19 June 2013. Lund University Press, Lund.

Heydari, E. 2008. Tectonic versus eustatic controls on supersequences of the Zagros Mountains of Iran. Tectonophysics 451, 56-70. DOI 10.1016/j.tecto.2007.11.046

Hints, O., Nõlvak, J., Viira, V. \& Mens, K. 2004. New palaeontological finds from the Tremadocian of Kadriorg, Tallinn, northern Estonia, 43-44. In HinTs, O. \& AinsAAR, L. (eds) WOGOGOB-2004 Conference Materials, Abstracts and Field Guide Book. Tartu University Press, Tartu.

Husserni, M.I. 1989. Tectonic and depositional model of Late Precambrian-Cambrian Arabian and adjoining plates. $A A P G$ Bulletin 73, 1117-31.

HusseinI, M.I. 1990. The Cambro-Ordovician Arabian and adjoining plates: a glacio-eustatic model. Journal of Petroleum Geology 13, 267-288.

DOI 10.1111/j.1747-5457.1990.tb00847.x

JACHOwICZ, M. 1995. Ordovician acritarch assemblages from central and northwestern Saudi Arabia. Review of Palaeobotany and Palynology 89, 19-25.

DOI 10.1016/0034-6667(94)00039-M

Jardiné, S., Combaz, A., Magloire, L., Peniguel, G. \& Vichy, G. 1974. Distribution stratigraphique des acritarches dans le Paléozoique du Sahara Algérien. Review of Palaeobotany and Palynology 18, 99-129. DOI 10.1016/0034-6667(74)90012-8

Jenkins, W.A.M. 1967. Ordovician Chitinozoa from Shropshire. Palaeontology 10, 436-488.

Jenkins, W.A.M. 1969. Chitinozoa from the Ordovician of Viola and Fernvale limestones of the Arbuckle Mountains, Oklahoma. Palaeontology, Special Paper 5, 1-44.

Jeppsson, L., Anehus, R. \& Fredholm, D. 1999. The optimal acetate buffered acetic acid technique for extracting phosphatic fossils. Journal of Paleontology 73, 957-965.

KING, W. 1846. Remarks on certain genera belonging to the class Palliobranchiata. Annals and Magazine of Natural History, Series 1 18, 26-42.

Konert, G., Al-Afifi, A.M. \& Al-HajRi, S.A. 2011. Paleozoic stratigraphy and hydrocarbon habitat of the Arabian Plate. GeoArabia 6, 407-422.

Le Hérissé, A., Al-Ruwaili, M., Miller, M. \& Vecoli, M. 2007. Environmental changes reflected by palynomorphs in the early Middle Ordovician Hanadir Member of the Qasim Formation, Saudi Arabia. Revue de Micropaleontology 50, 3-16. DOI 10.1016/j.revmic.2007.01.010

LI, J. 1987. Ordovician acritarchs from the Meitan Formation of Guizhou province, south-west China. Palaeontology 30, 613-634.

Li, J., Servais, T., YAn, K. \& Zhu, H. 2004. A nearshore-offshore trend in acritarch distribution from the Early-Middle Ordovician of the Yangtze Platform, South China. Review of Palaeobotany and Palynology 130, 141-161.

DOI 10.1016/j.revpalbo.2003.12.005

LinDSTRÖM, M. 1955. Conodonts from the lowermost Ordovician strata of south-central Sweden. Geologiska Foreningens $i$ Stockholm Förhandlingar 76, 517-604.

DOI 10.1080/11035895409453581

LiNDSTRÖM, M. 1971. Lower Ordovician conodonts of Europe. Geological Society of America Memoir 127, 21-61.

LOEBLICH, A.R. JR. 1970. Morphology, ultrastructure and distribution of Paleozoic acritarchs. Proceedings of the American Paleontological Convention in Chicago, Illinois 1969 (G) 2, 705-788.

Loeblich, A.R. JR. \& MacAdam, R.B. 1971. North American species of the Ordovician acritarch genus Aremoricanium. Palaeontographica, Abteilung B 135(1-2), 41-47.

Loeblich, A.R. JR. \& TAPPAN, H. 1976. Some new and revised or- 
ganic-walled phytoplankton microfossil genera. Journal of Paleontology 50, 301-308.

Lu, L.C. 1987. Acritarchs from Dawan Formation (Arenigian) of Huanghouchang in Yichang western Hubei. Acta Micropalaeontologica Sinica 4, 87-102.

Martin, F. 1969. Les acritarches de l'Ordovicien et du Silurian belges. Mémoires de l'Institut Royal des Sciences naturalles de Belgique 160, 1-175.

Martin, F. 1972. Les acritarches de l'Ordovicien de la Montagne Noire (Hérault, France). Bulletin de l'Institut Royal des Sciences naturelles de Belgique 48, 1-61.

Martin, F. 1984. New Ordovician (Tremadoc) acritarch taxa from the middle member of the Survey Peak Formation at Wilcox Pass, southern Canadian Rocky Mountains, Alberta. Geological Survey of Canada Paper 84-1A, 441-448.

Menke, C.T. 1828. Synopsis methodica Molluscorum generum omnium et specierum earum, quae in Museo Menkeano adservantur. 91 pp. Sumtibus auctoris, typis Henrici Gelpke, Pyrmonti. DOI 10.5962/bhl.title.16049

MolyneuX, S.G. 1988. Late Ordovician acritarchs from northeast Libya, 45-59. In Ei-Arnauti, A., Owens, B. \& Thusu, B. (eds) Subsurface Palynostratigraphy of Northeast Libya. Garyounis University, Benghazi.

Molyneux, S.G., Osterloff, P., Penny, R. \& SpaAk, P. 2006. Biostratigraphy of the Lower Paleozoic Haima Supergroup, Oman; its application in sequence stratigraphy and hydrocarbon exploration. GeoArabia 11, 17-48.

Nielsen, A.T. 2004. Ordovician sea level changes: a Baltic perspective, 84-93. In WebBy, B.D., PARIs, F., Droser, M.L. \& Percival, I.G. (eds) The Great Ordovician Biodiversification Event. Columbia University Press, New York.

Oterdoom, W.H., Worthing, M. \& Partington, M. 1999. Petrological and tectonostratigraphic evidence for a Mid Ordovician rift pulse on the Arabian Peninsula. GeoArabia 4, 467-500.

PAris, F. 1981. Les Chitinozoaires dans le Paléozoique du SudOuest de l'Europe. Bulletin de la Société géologique et minéralogique de Bretagne 26, 1-412.

PARIS, F. 1990. The Ordovician biozones of the North Gondwana Domain. Review of Palaeobotany and Palynology 66, 181-209. DOI 10.1016/0034-6667(90)90038-K

Paris, F., Boumendiel, K., Dabard, M.P., Ghienne, J.F., Loi, A., TANG, P., Videt, B. \& ACHAB, A. 2007b. Chitinozoan-based calibration of Early-Mid Ordovician transgressive events on northern Gondwana. Acta Palaeontologica Sinica 46, 370-375.

Paris, F., Grahn, Y.Y., Nestor, V. \& Lakova, I. 1999. A revised chitinozoan classification. Journal of Paleontology 73, 549-70.

Paris, F., Le Hérissé, A., Monod, O., Kozlu, H., Ghienne, J.F., Dean, W.T., Vecoli, M. \& Gunay, Y. 2007a. Ordovician chitinozoans and acritarchs from southern and southeastern Turkey. Revue de Micropaléontologie 50, 81-107. DOI 10.1016/j.revmic.2006.11.004

Paris, F., Verniers, J. \& Al-HajRI, S. 2000, Ordovician chitinozoans from Central Saudi Arabia. GeoArabia Special Publication 1, 42-56.

Playford, G. \& Martin, F. 1984. Ordovician acritarchs from the
Canning Basin, Westem Australia. Alcheringa 8, 187-223. DOI 10.1080/03115518408618943

Popov, L.E. 2000. Late Ordovician linguliformean microbrachiopods from north-central Kazakhstsan. Alcheringa 24, 257-75. DOI 10.1080/03115510008619531

Puente, G.S. DE LA 2010. Floian Chitinozoans (Lower Ordovician) from Santa Victoria area, Cordillera Oriental, northwestern Argentina: Systematics. Ameghiniana 47, 217-38.

Quintavalle, M. \& Playford, G. 2008. Stratigraphic distribution of selected acritarchs in the Ordovician subsurface, Canning Basin, Western Australia. Revue de Micropaléontologie 51, 23-37. DOI 10.1016/j.revmic.2006.11.003

RAEvsKAyA, E.G. 1999. Early Arenig acritarchs from the Leetse Formation (St Petersburg region, northwest Russia) and their palaeogeographic significance. Bollettino della Società Paleontologica Italiana 38, 247-256.

Rickards, R.B., Booth, G.A., Paris, F. \& Heward, A.P. 2010. Marine flooding events of the Early and Middle Ordovician of Oman and the United Arab Emirates and their graptolite, acritarch and chitinozoan associations. GeoArabia 15, 81-120.

Rickards, R.B., Wright, A.J. \& HAmedi, A.M. 2000. Late Ordovician and Early Silurian graptolites from southern Iran. Records of the West Australian Museum 58, 103-122.

Robardet, M., Henry, J.L., Nion, J., Paris, F. \& Pillet, J. 1972. La Formation du Pont-de-Caen (Caradocien) dans les synclinaux de Domfront et de Sees (Normandie). Annales de la Société Géologique du Nord 92, 117-137.

Rubinstein, C.V., Vecoli, M. \& Astini, R.A. 2011. Biostratigraphy and paleoenvironmental characterization of the Middle Ordovician from the Sierras Subandinas (NW Argentina) based on organic-walled microfossils and sequence stratigraphy. Journal of South American Earth Sciences 31, 124-138.

DOI 10.1016/j.jsames.2010.07.006

Samuelsson, J. \& Verniers, J. 2000. Ordovician chitinozoan biozonation of the Brabant Massif, Belgium. Review of Palaeobotany and Palynology 113, 105-29.

DOI 10.1016/S0034-6667(00)00055-5

SEILACHER, A. 1970. Cruziana stratigraphy of "non-fossiliferous" Palaeozoic sandstones, 447-476. In CRIMES, T.P. \& HARPER, J.C. (eds) Trace Fossils 2. Geological Journal, Special Issue 3. Seel House Press, Liverpool.

SenAlP, M. \& Al-DuAiJ, A. 2001. Qasim Formation: Ordovician storm- and tide-dominated shallow-marine siliciclastic sequences, Central Saudi Arabia. GeoArabia 6, 233-268.

Servais, T., Brocke, R. \& FAtKa, O. 1996. Variability in the Ordovician acritarch Dicrodiacrodium. Palaeontology 39, 389-405.

SetudehniA, A. 1975. The Palaeozoic Sequence at Zard Kuh and Kuh-e Dinar. Bulletin of the Iranian Petroleum Institute 60, 16-33.

Sharland, P.R., Casey, D.M., Davies, R.B., Simmons, M.D. \& Sutcliffe, O.E. 2004. Arabian Plate sequence stratigraphy. GeoArabia 9, 199-214.

Stouge, S. 2005. Barrandegnathus n. gen. (Conodonta) from the Komstad Limestone (lower Mid Ordovician), Scandinavia, and its palaeogeographical significance. Bulletin of the Geological Society of Denmark 52, 245-255. 
Stouge, S. \& Bagnoli, G. 1990. Lower Ordovician (Volkhovian-Kundan) conodonts from Hagudden, northern Öland, Sweden. Palaeontographia Italica 77, 1-54.

TAPPAN, H. \& LoEblich, A.R. 1971. Surface sculpture of the wall in Lower Paleozoic acritarchs. Micropaleontology 17, 385-410. DOI 10.2307/1484870

Taugourdeau, P. 1966. Les Chitinozoares, techniques d'études, morphologie et classification. Mémoire de la Société Géologique de France (nouvelle série) 45, 1-64.

Taugourdeau, P., Bouché, P., Combaz, A., Magloire, L. \& Millepied, P. 1967. Microfossiles organiques du Paléozoïque. Les Chitinozoaires. I. Analyse biblographique illustrée. 96 pp. Centre National de la Recherche Scientifique, Paris.

Taugourdeau, P. \& Jekhowsky, B. 1960. Répartition et description des Chitinozoaires Siluro-Dévoniens de quelques sondages de la C.R.E.P.S., de la C.F.P.A. et de la S.N. Repal au Sahara. Revue de l'Institut Français du Pétrole 15, 1199-1260.

Tongiorgi, M., Yin, L.M. \& Di Milia, A. 1995. Arenigian acritarchs from the Daping Section (Yangtze Gorges area, Hubei Province, Southern China) and their palaeogeographic significance. Review of Palaeobotany and Palynology 86, 13-48. DOI 10.1016/0034-6667(94)00097-4

Turner, B.R., Armstrong, H.A., Wilson, C.R. \& MaKhlouf, I.M. 2012. High frequency eustatic sea-level changes during the Middle to early Late Ordovician of southern Jordan: Indirect evidence for a Darriwilian Ice age in Gondwana. Sedimentary Geology 251-252, 34-48.

DOI 10.1016/j.sedgeo.2012.01.002

Turner, B.R., MaKhlouf, I.M. \& Armstrong, H.A. 2005. Late Ordovician (Ashgillian) glacial deposits in southern Jordan. Sedimentary Geology 181, 73-91.

DOI 10.1016/j.sedgeo.2005.08.004

VASLET, D. 1989. Late Ordovician glacial deposits in Saudi Arabia: A lithostratigraphic revision of the Early Paleozoic succession. Deputy Ministry for Mineral Resources, Ministry of Petroleum and Mineral Resources, Jiddah, Kingdom of Saudi Arabia, Professional Papers 3, 13-44.

VAslet, D. 1990. Upper Ordovician glacial deposits in Saudi Arabia. Episodes 13, 147-161.

VAVRDOVÁ, M. 1965. Ordovician acritarchs from central Bohemia. Věstník Ústředního ústavu geologického 40, 351-357.

VAVRDovÁ, M. 1966. Palaeozoic microplankton from central Bohemia. Časopis pro mineralogii a geologii 11, 409-414.

VavrdovÁ, M. 1972. Acritarchs from the Klabava Shales (Arenig). Věstník Ústředního ústavu geologického 47, 79-86.

VAVRDOVÁ, M. 1990. Early Ordovician acritarchs from locality Myto near Rokycany (late Arening, Czechoslovakia). Časopis pro mineralogii a geologii 35, 239-50.

Vecoli, M. \& Le Hérissé, A. 2004. Biostratigraphy, taxonomic diversity and patterns of morphological evolution of Ordovician acritarchs (organic-walled microphytoplankton) from the northern Gondwana margin in relation to palaeoclimatic and palaeogeographic changes. Earth-Science Reviews 67, 267-311. DOI 10.1016/j.earscirev.2004.03.002

Vecoli, M., Tongiorgi, M., Abdesselam-Roughi, F., Benzarti,
R. \& Massa, D. 1999. Palynostratigraphy of Upper Cambrian-Upper Ordovician intracratonic clastic sequences, North Africa. Bollettino della Società Paleontologica Italiana 38, 331-341.

Videt, B., Paris, F., Rubino, J.L., Boumendjel, K., Dabard, M.P., Loi, A., Ghienne, J.F., Marante, A. \& Gorini, A. 2010. Biostratigraphical calibration of third-order Ordovician sequences on the northern Gondwana platform. Palaeogeography, Palaeoclimatology, Palaeoecology 296, 359-375.

DOI 10.1016/j.palaeo.2010.03.050

ViLLAS, E. 1995. Caradoc through Early Ashgill brachiopods from the Central-Iberian Zone (Central Spain). Geobios 28, 49-84. DOI 10.1016/S0016-6995(95)80204-5

WaAgen, W. 1883. Salt Range fossils, vol. I, part 4. Productus Limestone fossils, Brachiopoda. Memoirs of the Geological Survey of India, Palaeontologia Indica (series 13) 2, 391-546.

Wang, X.F., Stouge, S., Chen, X.H., Li, Z.H. \& Wang, C.S. 2009. Dapingian Stage: standard name for the lowermost global stage of the Middle Ordovician Series. Lethaia 42, 377-380. DOI 10.1111/j.1502-3931.2009.00169.x

Wang, X.F., Stouge, S., Erdtmann, B.D., Chen, X.H., Li, Z.H., WAng, C.S., Zeng, Q.L., Zhou, Z.Q. \& Chen, H.M. 2005. A proposed GSSP for the base of the Middle Ordovician Series: the Huanghuachang section, Yichang, China. Episodes 28, 105-117.

Webby, B.D., Cooper, R.A., Bergström, S.M. \& PAris, F. 2004. Stratigraphic framework and times slices, 41-47. In WeBBy, B.D., Paris, F., Droser, M. \& Percival, I.G. (eds) The Great Ordovician Biodiversification Event. Columbia University Press, New York.

Winchester-Seeto, T., Foster, C. \& O'Leary, T. 2000. Chitinozoans from the Middle Ordovician (Darriwilian) Goldwyer and Nita formations, Canning Basin (Western Australia). Acta Palaeontologica Polonica 45, 271-300.

YAN, K., LI, J. \& LiU, J. 2005. Biodiversity of Early-Middle Ordovician acritarchs and sea level changes in South China. Chinese Science Bulletin 50(20), 2362-2368.

Yin, L., Di Milia, A. \& Tongiorgi, M. 1998. New and emended acritarch taxa from the lower Dawan Formation (lower Arenig, Huanghuachang Section, South China). Review of Palaeobotany and Palynology 102, 223-248. DOI 10.1016/S0034-6667(98)00037-2

ZHEN, Y.Y. 1985. The biostratigraphic significance of the chitinozoans from the Meitan Formation at Honghuayuan, Northern Guizhou. Scientia Geologica, Sinica 4, 375-379. [in Chinese with English summary]

Zhen, Y.Y., Percival, I.G., Cooper, R.A., Simes, J.E. \& Wright, A.J. 2009. Darriwilian (Middle Ordovician) conodonts from Thompson Creek, Nelson Province, New Zealand. Memoirs of the Association of Australasian Palaeontologists 37, 25-53.

Zhen, Y.Y., Percival, I.G. \& Webby, B.D. 2003. Early Ordovician conodonts from western New South Wales, Australia. Records of the Australian Museum 55, 169-220.

DOI 10.3853/j.0067-1975.55.2003.1383 